\title{
Bird faunas of the humid montane forests of Mesoamerica: biogeographic patterns and priorities for conservation
}

\author{
BLANCA E. HERNÁNDEZ-BAÑOS, A. TOWNSEND PETERSON, \\ ADOLFO G. NAVARRO-SIGÜENZA, and B. PATRICIA \\ ESCALANTE-PLIEGO
}

\section{Summary}

The distribution of 335 species of birds in 33 islands of humid montane forest in Mesoamerica is summarized, and patterns of distribution, diversity and endemism are analysed. The montane forests of Costa Rica and western Panama far exceed other habitat islands considered for species-richness, richness of species endemic to Mesoamerica, and richness of species ecologically restricted to humid montane forests. Other regions, such as the Sierra Madre del Sur of Guerrero and Oaxaca, the Los Tuxtlas region of southern Veracruz and the mountains of Chiapas and Guatemala, also hold rich and endemic avifaunas. Based on patterns of similarity of avifaunas, the region can be divided into seven regions holding distinctive avifaunas (Costa Rica and western Panama; northern Central America and northern Chiapas; southern Chiapas; eastern Mexico north of the Isthmus of Tehuantepec; Sierra Madre del Sur; interior Oaxaca; and Transvolcanic Belt and Sierra Madre Occidental), which serve as useful guides for the setting of priorities for conservation action.

Se resumen las distribuciones de 335 especies de aves en 33 islas de bosque húmedo de montaña en Mesoamérica, y se analizan patrones de distribución, diversidad y endemismo. Los bosques montanos de Costa Rica y del oeste de Panamá tienen la más alta riqueza de especies, riqueza de especies endémicas a Mesoamerica, y riqueza de especies ecologicamente restringidas a bosque húmedo de montaña. Otras regiones, tales como la Sierra Madre del Sur de Guerrero y Oaxaca, la región de Los Tuxtlas y las montañas de Chiapas y Guatemala, también tienen avifaunas ricas en especies y en endémicas. Basado en patrones de similitud de avifaunas, se puede dividir Mesoamerica en siete regiones que tienen avifaunas distintas (Costa Rica y el oeste de Panamá; el norte de Centroamérica y el norte de Chiapas; el sur de Chiapas; el este de México; la Sierra Madre del Sur; el interior de Oaxaca; y el Eje Neovolcánico y la Sierra Madre Occidental), las cuales pueden servir como guias en el establecimiento de prioridades para la conservación.

\section{Introduction}

Tropical forests are rapidly disappearing from the face of the earth, and with them are vanishing multitudes of species of plants and animals that depend on them for food and shelter. Reductions in forest cover in this century are frighteningly large, and have accelerated greatly in recent years owing to 
expanding human populations, worsening economic situations, and improved technology for forest removal. For this reason, tropical forests have become the focus of intense interest from conservationists working to avoid large-scale loss of biological diversity (Sarukhán and Dirzo 1992).

In spite of the interest in preserving tropical forest biodiversity, the geographic distribution of that diversity is still largely unknown (Peterson et al. 1993). That is, for most taxonomic groups, very little is known about distributional limits of species, patterns of species-richness, or patterns of distribution of unique or endemic forms (Soulé 1990, Escalante-Pliego et al. 1993, Peterson et al. 1993). Birds are an important group for such studies because their taxonomy is well known, and because inventory methods are well developed, permitting detailed inferences from distributional data (e.g. ICBP 1992). Among the purposes of this paper, therefore, are to summarize the current knowledge of the distribution of birds in one habitat type - humid montane forests - in Mesoamerica, to analyse that information with regard to biogeographic patterns, and to begin to outline strategies for conservation action.

\section{Humid montane forests in Mesoamerica}

For this paper, we define humid montane forest as middle-to-high elevation tropical forest that receives strong input of moisture from rain, fog, and clouds. This definition includes true cloud-forest, which is a dense mixture of temperate and tropical broad-leaved tree species with many epiphytes and tree ferns, as well as humid pine-oak forest. Tree species characteristic of northern Mesoamerican cloud-forests include members of the genera Quercus, Juglans, Podocarpus, and especially Liquidambar (east) and Chiranthodendron (west; Rzedowski 1986). Many genera and species of trees in eastern Mexican cloud-forests are also found in the eastern United States, probably indicating an ancient moist forest connection between the two regions (Martin and Harrell 1959). Humid pine-oak forests grade into true cloud-forests, and share with them structural features such as the abundance of tree ferns and epiphytes (Rzedowski 1986). Faunas of the two habitat types, when in contact, are almost identical (Navarro-Sigüenza 1992, Torres-Chávez 1992), and therefore are considered together herein (Escalante-Pliego et al. 1993, Peterson et al. 1993).

Humid montane forests are found in broken strings along both coastal slopes of Mesoamerica. This distribution makes intuitive sense: coastal mountains intercept moisture from clouds rolling in off the ocean. These forests are better developed in the east, where climatic conditions are more moist. The degree of development of cloud-forests in a particular region also depends on factors such as soil type and predominant weather patterns, but especially on the presence of high or steeply ascending mountains close to the coast. Hence, the geographic distribution of the habitat is everywhere fragmented and local (Figure 1).

The dominant geographic features in Mexico are coastal ranges ("cordilleras") and interior basins. The western cordillera consists of the Sierra Madre Occidental in the north-west, part of the Transvolcanic Belt from Jalisco south to Michoacán, the Sierra Madre del Sur of Oaxaca and Guerrero, and the Sierra Madre de Chiapas. The eastern cordillera includes the Sierra Madre Oriental in the north-east; part of the Transvolcanic Belt in Hidalgo, Puebla, and Veracruz; 


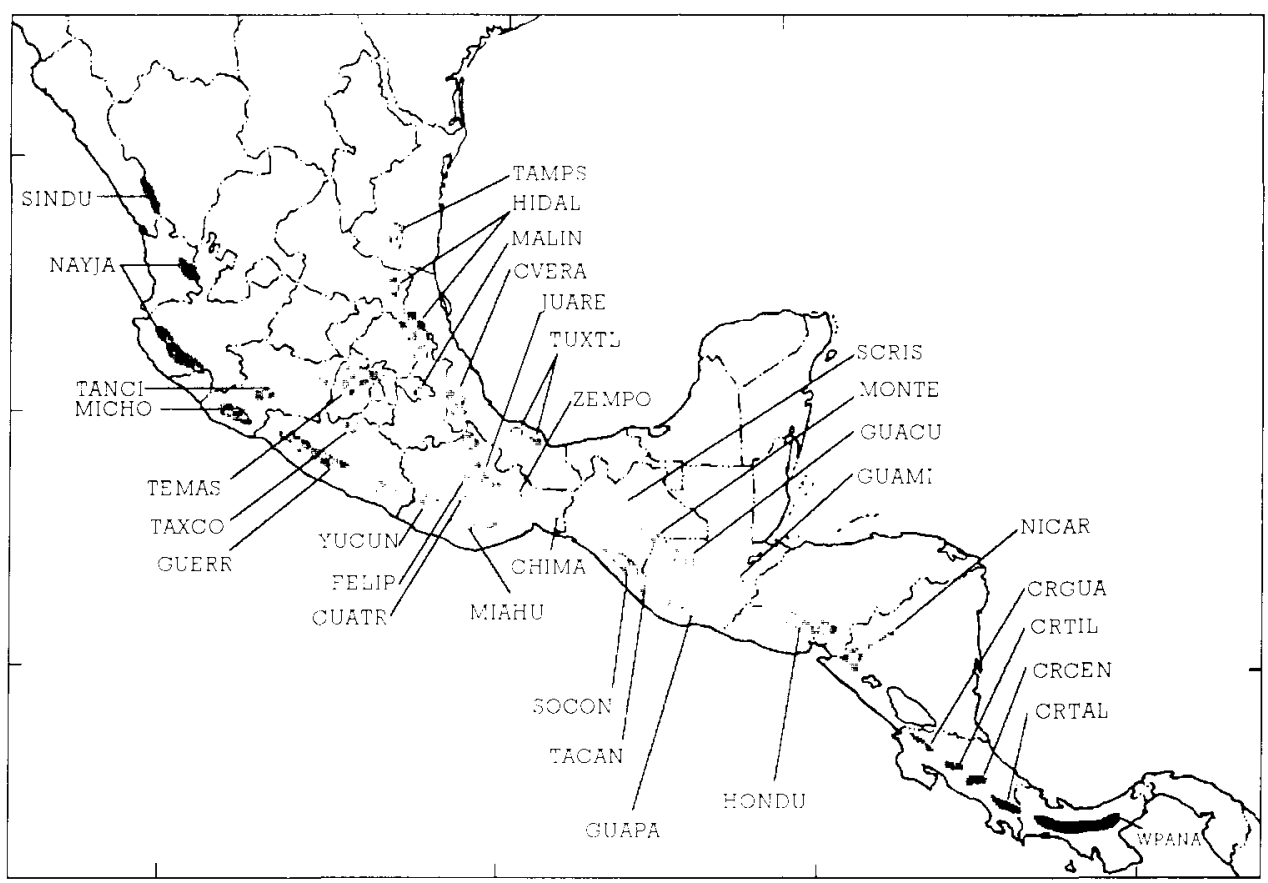

Figure 1. Map of the distribution of patches of humid montane forest in Mesoamerica, showing those included in this study and several that are yet to be studied.

the Nudo de Zempoaltépetl of Oaxaca; and the Sierra Norte de Chiapas. Separating these two mountain chains are arid interior basins including the Chihuahuan Desert, Valle de Tehuacán, Valle de Oaxaca, and the interior basins of Chiapas. Farther south, in southern Central America, the topography is often more simple, with one central cordillera and lowlands along both coasts.

An east-west transect across Mexico at almost any latitude therefore crosses a remarkably consistent set of vegetation types. First, one encounters wet tropical habitats in the Atlantic coastal lowlands. On the coastal slope of the first range of mountains is a narrow band of cloud-forest, and above that a band of humid pine-oak forest: these two habitats are the focus of the present paper. At the highest elevations, alpine pine-fir forest is found. In the interior basins, dry pine-oak forest, desert, or deciduous tropical scrub prevails. Descending the western slope, the same sequence of habitats is found, from alpine pine-fir forest through humid pine-oak and cloud-forest down to lowland tropical forests. However, because climates of the western lowlands are often less humid than those of the eastern slope, the west-slope tropical forests rarely approach the lush, evergreen quality of the east slope, and indeed are in many cases wholly or partly deciduous. Much of the geography of habitats in the country can be understood on the basis of this simplified scheme. Distributions of vegetation types in Central America are similar, except that in many areas the dry interior basins are lacking, and humid montane forest is therefore more continuous (Long 1995). 


\section{Mesoamerican humid montane forest avifaunas}

The birds of humid montane forests in Mesoamerica represent a surprisingly diverse aggregation of species, and rank high among habitats in Mexico in total species-richness (Navarro-Sigüenza 1992, Escalante-Pliego et al. 1993, Peterson et al. 1993, Long 1995). Among the birds present are species commonly associated with lowland rainforests (e.g. Ornate Hawk-eagle Spizaetus ornatus, Ochre-bellied Flycatcher Mionectes oleagineus), as well as species typical of high-elevation, alpine forests (e.g. Sharp-shinned Hawk Accipiter striatus, Golden-crowned Kinglet Regulus satrapa). Also present, and perhaps most interesting, are many species and genera that are restricted to the humid montane forest zone, such as toucanets of the genus Aulacorhynchus, several rare and endangered guans (genera Penelopina, Oreophasis, and Chamaepetes), and jays of the genus Cyanolyca.

This variety suggests several ideas about why humid montane forests hold such diverse avifaunas (Escalante-Pliego et al. 1993). One possibility is that they represent a meeting ground between habitats, and their avifaunas largely consist of mixtures of both lowland and highland elements. A second view is that Mesoamerica as a whole represents an area of overlap between two faunas those of North and South America - and that its richness results from the intermixture of the two geographically separated avifaunas. A final possibility is that substantial diversification has occurred in situ, and that the increased diversity of humid montane forests results from speciation and diversification of bird taxa in humid montane forests. It should be noted that these three explanations are not mutually exclusive, and that one, two, or all three may actually have played roles in the development of the humid montane forest avifauna.

Hence, a second set of objectives for this study is to lay a basis for a more thorough understanding of the historical processes that generated the diverse humid montane forest avifauna. Detailed analyses of patterns of distribution, diversity, and endemism can reveal hints as to the history of the region and its biota. Later, combining these results with hypotheses of the history of particular taxa - phylogenetic hypotheses - detailed historical explanations can potentially be developed.

\section{Methods}

We gathered data on the distribution of bird species in 33 isolated patches of humid montane forest in Mesoamerica (Figure 1 ), defined here as the region lying between the Río Bravo (U.S.A.-Mexico border) and the Isthmus of Panama. Forest patches were chosen to represent as much as possible regions of continuous humid montane forest without major interruptions such as deep river valleys or desert basins. Some patches had to be eliminated from consideration owing to insufficient data; for example, the Sierra Mazateca of northern Oaxaca was not considered because nothing whatsoever was known of its avifauna (Binford 1989; results of surveys are currently in preparation). Obviously, because humid montane forest is by nature fragmented, our "patches" really represent systems of related patches of different sizes; badly 
needed are surveys in tiny and remote humid montane forest patches. Because of the concentration of our field surveys in the northern part of the study area (Mexico), more detailed analysis was possible within Mexico than in the mountain systems in Central America; regardless, cloud-forest patches appear to be more continuous in Central America (ICBP 1992, Long 1995), making a coarser-grained view appropriate. Detailed analyses of the extent and condition of individual forest patches, as well as analyses of species-area relationships, must await detailed study of satellite imagery from the region.

Three hundred and thirty-five bird species were included in the database for this study, based on the taxonomy of the American Ornithologists' Union (AOU 1983), with minor amendments to reflect more recent taxonomic opinion (Appendix 1). We used brackets [ ] to indicate the superspecies relationships of differentiated allopatric forms that would be considered semispecies (AOU 1983) or phylogenetic species (Cracraft 1983, McKitrick and Zink 1988). To restrict the analysis to taxa that actually breed in the study areas, we eliminated all species that occur only as migrants, vagrants, or winter residents (Remsen 1994). A few species, which have broad geographic distributions but occur in humid montane forests only marginally throughout much of their ranges, such as Scrub Jays Aphelocoma coerulescens, are included in the data matrix only where they range broadly into that habitat.

To focus the study on inhabitants of humid montane forests, we excluded species not living within the forest, for example, swallows that hunt for food above the canopy; families of birds that were thus eliminated include Hirundinidae and Alcedinidae. Based on descriptions of distributions (AOU 1983) and habitat use (see references), we described each species as occurring farther north $(N=1)$, farther south $(S=1)$, higher $(A=1)$, or lower $(B=1)$ in the altitudinal sequence of habitats. We define species occurring neither farther north nor farther south $(\mathrm{N}+\mathrm{S}=\mathrm{o})$ as endemic to Mesoamerica, and species occurring neither higher nor lower in the altitudinal sequence of habitats $(\mathrm{A}+\mathrm{B}=0)$ as ecologically restricted to humid montane forests.

A wide variety of sources (e.g. Friedmann et al. 1950, Miller et al. 1957, Wetmore 1965-1984, AOU 1983, Stiles and Skutch 1989) was used to make the database reflect the known distributions of species as completely as possible. In addition, we consulted taxonomic treatments for many groups, faunal lists for numerous localities, and specimen data from several North American museum collections. For each definite record, a " 1 " indicating presence was entered in the appropriate cell of the data matrix; absences were entered as " 0 ". Because, in many cases, existing inventories for particular montane forest habitat islands were incomplete, we also included a "probable" occurrence category: if a species occurred in habitat islands both north and south of an island in question, and if particuliar habitat requirements were met, then an " $X$ " was entered in the appropriate cell of the data matrix. Later, we tested the validity of these distributional assumptions by alternatively setting all $X=1$ (assumptions correct) or all $X=O$ (assumptions incorrect), and reanalysing the data.

A variety of approaches was employed to understand geographic patterns in the dataset. Species-richness and levels of endemism were assessed by simple counts of occurrences at each locality. Phenetic analyses of similarity among avifaunas of different localities were conducted by calculating Simpson's Index 
of Faunal Similarity, and then using the unweighted pair-group method of analysis (routines in SYSTAT, version 3.1) to produce dendrograms. Reanalysing the data under the two distributional assumptions mentioned above had no qualitative effect on patterns detected, and so only the results based on the most complete information (assumption $X=1$ ) are presented herein.

\section{Results}

\section{Patterns of species-richness and endemism}

Species-richness of birds in the humid montane forest islands in Mesoamerica showed a broadly increasing trend from north to south (Table 1, Figure 2a). Forest islands in northern and central Mexico generally held too bird species or fewer, those in Chiapas and northern Central America 150-180 species, and those of Costa Rica and western Panama 180-201 species. Hence, the coarsest-scale trend was one of elevated species-richness in the southernmost montane forest islands.

Exceptions to this trend included montane forest islands in the interior and those that are geographically isolated from the main mountain masses of Mesoamerica. For example, the forest islands in the interior of Mexico in the Transvolcanic Belt and central Oaxaca (Table 1, Figure 2a) held substantially fewer species than adjacent forest islands on the coastal slopes. Similarly, the isolated humid montane forests of the Los Tuxtlas region of south-eastern Veracruz held relatively few bird species (Andrle 1967). Surveys in small and isolated habitat islands in southern Mesoamerica would provide an important test of the generality of this result.

In all, 145 species of birds that occur in humid montane forests are endemic to Mesoamerica (i.e. $\mathrm{N}+\mathrm{S}=0$ ). Patterns of species-richness among endemics of Mesoamerica were generally similar to patterns of species-richness in the region (Table 1, Figure 2b): northernmost forest islands contained few Mesoamerican endemics, whereas Central American forest islands, especially those of Costa Rica and western Panama, were extremely rich in such species. These patterns were apparent regardless of whether they were based on raw numbers of endemic species or on the percentage of endemism relative to the total species-richness at the site.

\section{Patterns of distribution of habitat-restricted species}

A total of 147 species occur in Mesoamerica that are ecologically restricted to humid montane forests (i.e. $A+B=0$ ). These species are narrowly restricted to the humid forest band at middle elevations ( $1,000-1,800 \mathrm{~m}$ in Mexico). Geographic patterns of richness of these taxa were generally similar to those of species-richness: a broad trend of increasing numbers from north to south (Table 1, Figure 2c). Especially notable was the virtual absence of ecologically restricted species in the marginal northernmost forest islands in northern, central and western Mexico. 


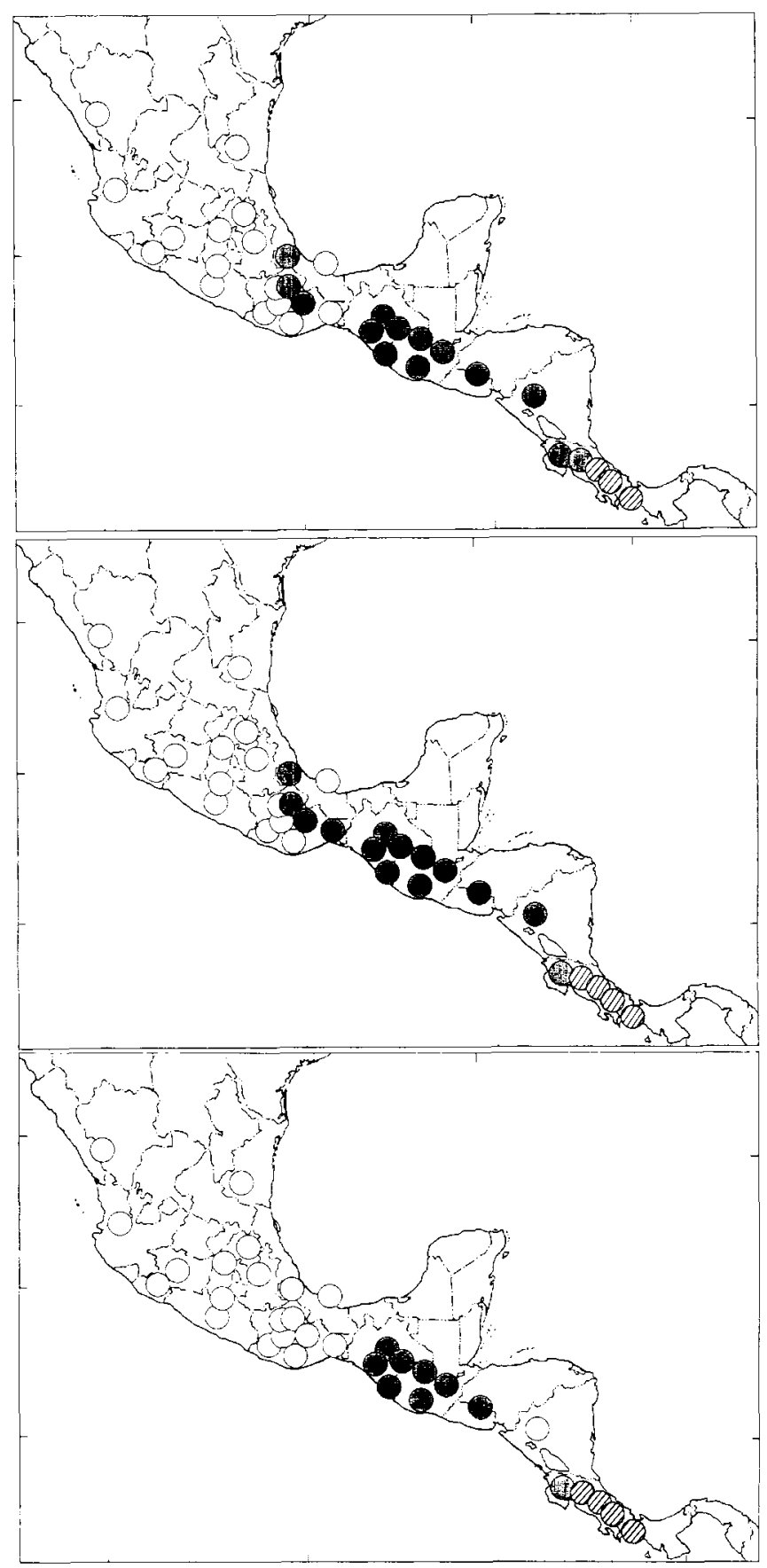

Figure 2. Distribution of species-richness of birds in the humid montane forests of Mesoamerica. Top: species-richness (white, 72-99; light grey, 100-136; dark grey, 145-178; cross-hatched, 195-200 species). Middle: richness of species endemic to Mesoamaerica (white, 3-11; light grey, 12-25; dark grey, 26-39; cross-hatched, 40-57 species). Bottom: richness of species restricted to humid montane forests (white, 7-15, light grey, 16-27; dark grey, 36-62; cross-hatched, 79-102 species). 
Table 1. Summary of species-richness, richness of species ecologically restricted to humid montane forests, richness of species endemic to the humid montane forests of Mesoamerica, and richness of narrow endemics (at scales of 1-2 patches, 1-5 patches, and 1-10 patches), of 33 humid montane forest patches in Mesoamerica. $X_{0}$ and $X_{I}$ represent the two different assumptions made regarding completeness of inventories in each forest patch. Totals refer to numbers in each category in Mesoamerica as a whole.

See Appendix 2 for patch names.

\begin{tabular}{|c|c|c|c|c|c|c|c|c|c|}
\hline \multirow[b]{2}{*}{ Patch } & \multicolumn{2}{|c|}{ Species-richness } & \multicolumn{2}{|c|}{ Ecolog. restricted } & \multicolumn{2}{|c|}{ Endemic } & \multicolumn{3}{|c|}{ Narrow endemics } \\
\hline & Xo & $X_{I}$ & $X_{0}$ & $X_{1}$ & $x_{0}$ & $X_{I}$ & $1-2$ & $1-5$ & $1-10$ \\
\hline
\end{tabular}

Eastern Mexico

\section{TAMPS}

HIDAL

CVERA

TUXTL

CUATR

JUARE

FELIP

ZEMPO

SCRIS

MONTE

$\begin{array}{rr}79 & 103 \\ 100 & 136 \\ 139 & 175 \\ 82 & 104 \\ 42 & 72 \\ 125 & 154 \\ 78 & 104 \\ 71 & 154 \\ 81 & 165 \\ 34 & 166\end{array}$

$\begin{array}{rl}13 & 14 \\ 23 & 27 \\ 36 & 41 \\ 18 & 24 \\ 8 & 10 \\ 34 & 38 \\ 15 & 17 \\ 21 & 36 \\ 36 & 51 \\ 17 & 51\end{array}$

$\begin{array}{rr}8 & 8 \\ 12 & 15 \\ 20 & 23 \\ 11 & 14 \\ 4 & 5 \\ 20 & 22 \\ 7 & 9 \\ 12 & 20 \\ 27 & 36 \\ 12 & 36\end{array}$

Western Mexico

\begin{tabular}{|c|c|c|c|c|c|c|c|c|c|}
\hline SINDU & 36 & 95 & 4 & 10 & 3 & 4 & 1 & 1 & 1 \\
\hline NAYJA & $7^{1}$ & 122 & 12 & 17 & 9 & 9 & 1 & 1 & 2 \\
\hline $\mathrm{MICHO}$ & 78 & 113 & 9 & 14 & 5 & 8 & $\mathrm{o}$ & o & 1 \\
\hline GUERR & 111 & 133 & 25 & 27 & 15 & 15 & 1 & 2 & 3 \\
\hline YUCUÑ & 68 & 103 & 15 & 16 & 6 & 6 & 1 & 2 & 2 \\
\hline MIAHU & 99 & 124 & 23 & 24 & 12 & 12 & 1 & 2 & 3 \\
\hline CHIMA & 97 & 120 & 32 & 36 & 21 & 22 & o & 0 & 4 \\
\hline SOCON & 79 & 155 & 44 & 56 & 30 & 37 & $O$ & 2 & 14 \\
\hline TACAN & 65 & 156 & 36 & 57 & 27 & 38 & 0 & 2 & 15 \\
\hline
\end{tabular}

Transwolcanic Belt, Mexico

TANCI 58

TEMAS

TAXCO

MALIN

$\begin{array}{rr}8 & 11 \\ 7 & 11 \\ 7 & 7 \\ 0 & 7\end{array}$

4
4
4
0

\section{Central America}

\begin{tabular}{|c|c|c|c|c|c|c|c|c|c|}
\hline GUAPA & 145 & 178 & 52 & 58 & 36 & 38 & 0 & 3 & 16 \\
\hline GUACU & 88 & 183 & 40 & 59 & 30 & 39 & o & 2 & 16 \\
\hline GUAMI & 95 & 181 & 38 & 58 & 26 & 38 & o & 1 & 15 \\
\hline HONDU & 173 & 183 & 60 & 62 & 38 & 39 & 1 & 2 & 16 \\
\hline NICAR & 91 & 147 & 26 & 43 & 20 & 23 & 1 & 2 & 6 \\
\hline CRGUA & 130 & 145 & 53 & 58 & 26 & 28 & 0 & 18 & 20 \\
\hline CRTIL & 159 & 170 & 74 & 79 & 38 & 40 & 0 & 28 & 30 \\
\hline CRCEN & 193 & 195 & 96 & 97 & 54 & 54 & o & $4^{1}$ & 43 \\
\hline CRTAL & 190 & 195 & 97 & 99 & 56 & 56 & 3 & 43 & 45 \\
\hline WPANA & 188 & 200 & 97 & 102 & 56 & 57 & 6 & 45 & 47 \\
\hline TOTALS & \multicolumn{2}{|c|}{335} & \multicolumn{2}{|c|}{147} & \multicolumn{2}{|c|}{101} & 14 & 61 & 78 \\
\hline
\end{tabular}


Of the ecologically restricted species, more than two-thirds (101 species) are also geographically restricted to Mesoamerica (i.e. $N+S+A+B=0$ ). This assemblage of species is found nowhere in the world but in Mesoamerican humid montane forests, and might be taken as a set of species that evolved in situ. These species are of special interest in conservation planning because of their extreme vulnerability to destruction of humid montane forests in a limited region.

\section{Narrow endemics}

Species with extremely restricted distributions, "narrow endemics", are important features in studies of biological diversity and endemism. Of the 335 species included in this study, 101 were endemic to Mesoamerican humid montane forests. Of these species, eight (7.9\%) were restricted completely to a single forest island; $14(13.9 \%)$ were found in one or two islands; and 61 $(60.4 \%)$ were found in fewer than five islands of montane forest. Hence, extreme geographic restriction is common among the endemic birds of humid montane forests in Mesoamerica.

The geographic distribution of these restricted-distribution species was focused in but a few zones (Figure 3). Species with geographic ranges of but one or two forest islands were concentrated in the Los Tuxtlas region of southeastern Veracruz, the mountains of western Mexico, and especially in southeasternmost Costa Rica and western Panama. Each of these areas represents a mountain massif holding forests which were probably isolated from other humid montane forests since before the Pleistocene (Martin and Harrell 1959, Graham 1993), providing the isolation necessary for speciation to take place. Expanding the scale of endemism to include species with geographic ranges of five or fewer forest islands, the pattern was similar, although forest islands in north-eastern Mexico also appeared as hotspots, and the importance of the Costa Rican and Panamanian islands became much more emphasized. Expanding the scale still more, say, to ranges of up to 10 forest islands, emphasized Chiapas, Guatemala, Costa Rica and western Panama greatly, and deemphasized the importance of forest islands farther north. Hence, the geographic patterning of endemism is very much a function of the spatial scale at which endemism is defined.

\section{Patterns of similarity among avifaunas}

Analyses of similarity among avifaunas of different forest islands (Figure 4) revealed clear geographic patterns. The avifaunas of the mountains of Costa Rica and western Panama were very different from those of forest islands farther to the north. The avifaunas of the forest islands of eastern Mexico north of the Isthmus of Tehuantepec were all very similar to one another, and as a unit were most similar to those of Chiapas and northern Central America (within which the mountains of southern Chiapas segregated as a distinct entity). Three forest islands, the Chimalapas region of eastern Oaxaca, the Los Tuxtlas region of south-eastern Veracruz, and the mountains of Nicaragua, clustered loosely together, which, at least in the case of the latter island, makes no clear geo- 

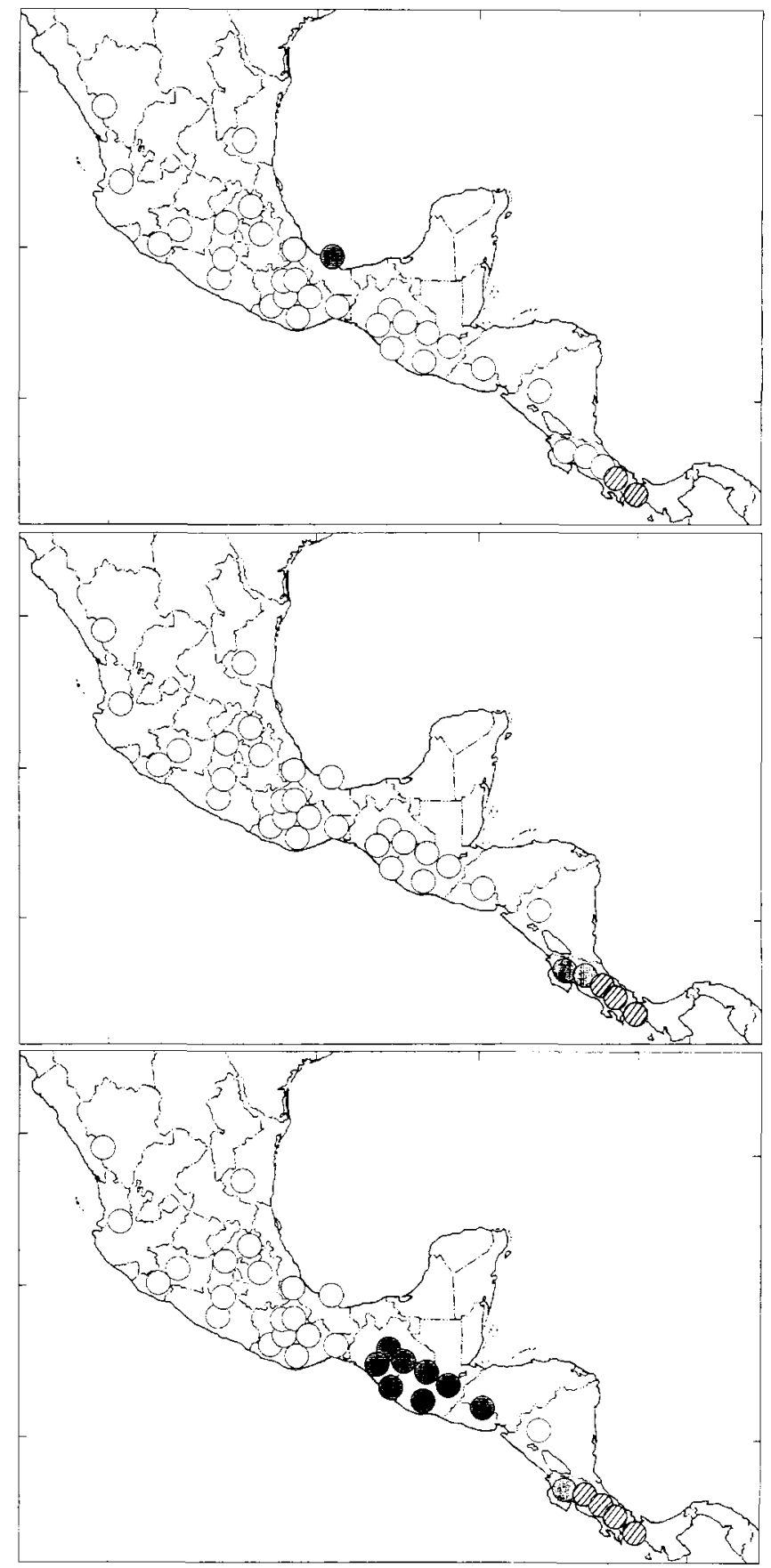

Figure 3. Distribution of richness of species of restricted geographic distribution (narrow endemics) in Mesoamerica, under different definitions of endemism. Top: $1-2$ forest patches (white, 0; light grey, 1; dark grey, 2; cross-hatched, 3-6 species). Middle: 1-5 forest patches (white, 0 ; light grey, 1-3; dark grey, 18-28; cross-hatched, 41-45 species). Bottom: 1-10 forest patches (white, 0; light grey, 1-6; dark grey, 14-20, cross-hatched, $30-47$ species). 


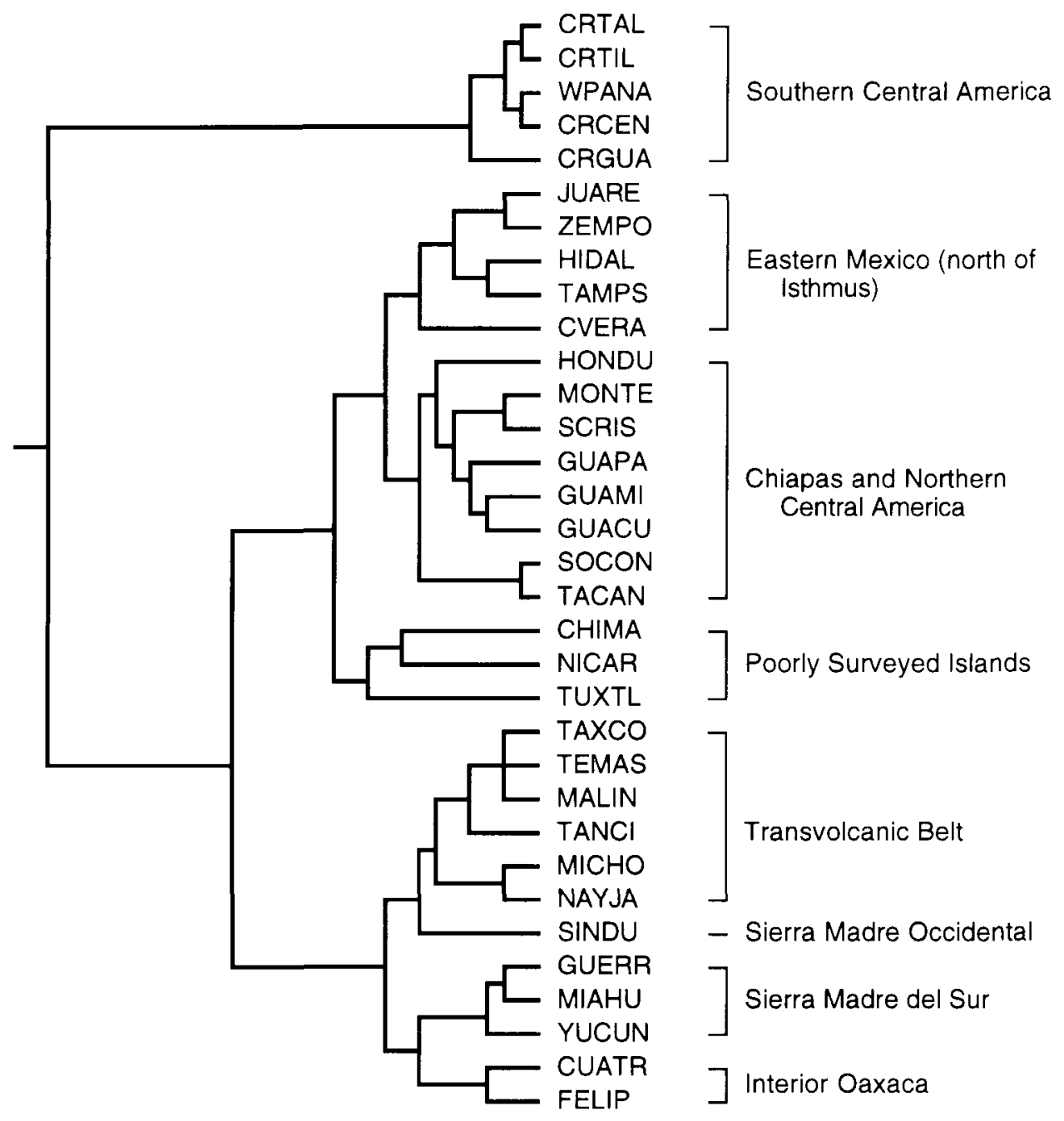

Figure 4. Patterns of similarity among the avifaunas of patches of humid montane forest in Mesoamerica, based on UPGMA analyses of Simpson's Index of faunal similarity.

graphic sense, although given their low level of similarity, they could perhaps be considered as three separate entities; perhaps they grouped together because their avifaunas are depauperate and/or poorly known. Finally, the forest islands of the Transvolcanic Belt and Sierra Madre Occidental of central and western Mexico (within which can be seen three geographic groupings: the Sierra Madre Occidental, the mountains along the coast from Michoacán to Nayarit, and the interior portion of the Transvolcanic Belt) and the mountains of southern Mexico west of the Isthmus of Tehuantepec (within which can be discerned a Sierra Madre del Sur group and an interior Oaxaca group) each formed units, and grouped together form a more inclusive unit separate from that of eastern Mexico and northern Central America. Hence, most forest islands included in 


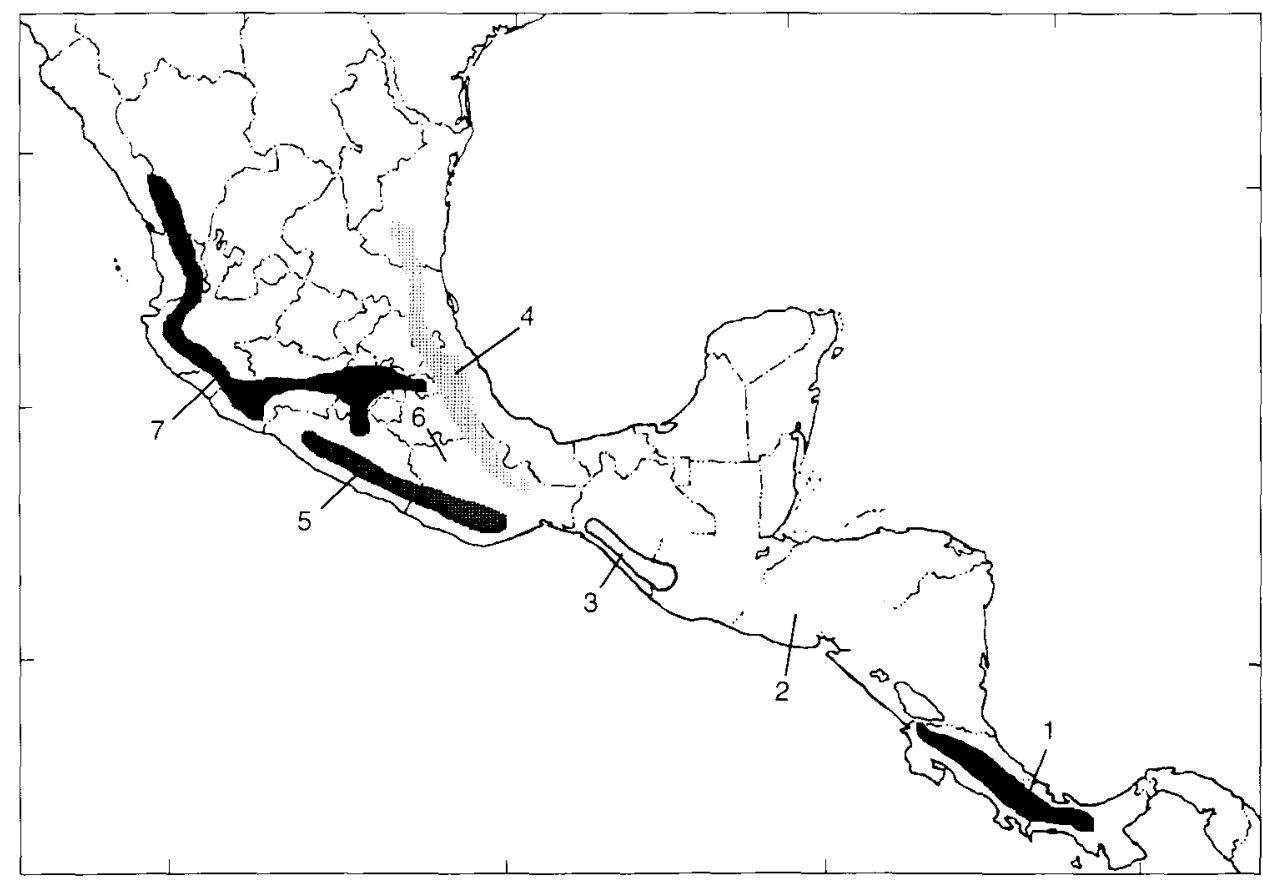

Figure 5. Biogeographic units based on patterns of similarity of avifaunas in the humid montane forests of Mesoamerica (numbers are equivalent to those on opposite page).

this study fell into distinct geographic units, and biogeographic entities were thereby easily delineated (Figure 5).

\section{Discussion}

Geographic patterns in distribution of species

The avifauna of the humid montane forests of Mesoamerica is distributed unevenly. A general trend of increasing diversity from north to south across the study area was found, with the southernmost islands holding about twice as many species as the northernmost. Also, patches of humid montane forest isolated from the main cordilleras had considerably fewer species than central patches. All of these patterns were perhaps expected given the ease of colonization of central as compared with peripheral forest patches, long-term stability and integrity of forest patches, patterns of complexity of plant communities, and the broad-scale trend of increasing diversity at lower latitudes.

More interesting were the geographic patterns of distribution of species endemic to Mesoamerican humid montane forests. By far the greatest concentration of endemic species in the region was in south-eastern Costa Rica and western Panama. This result would seem surprising in view of the geographic proximity of the cloud-forests of eastern Panama and the Andes of South America; however, as has been appreciated by other authors (e.g. Wetmore 1965-1984, ICBP 1992, Long 1995), many species have their geographic distributions 
restricted to a tiny area very close to a barrier that separates the Mesoamerican and South American faunas. Such a concentration, with essentially no introgression from forms to the east, suggests that the Isthmus of Panama has constituted an extremely strong barrier to dispersal, that colonization events in either direction have been rare, and that connections of humid "montane" forest across the Isthmus were probably never established during the climatic fluctuations of the late Pleistocene glaciations.

\section{Biogeographic boundaries}

The analyses presented herein, especially the cluster analyses of avifaunal similarity (Figure 4), allowed detailed and quantitative identification of biogeographic regions (Figure 5). The analyses presented above clearly identified seven geographic clusters with characteristic avifaunas. In the list that follows, endemic species are listed, and selected species having distributions almost limited to the region are given in parentheses.

(1) Costa Rica and western Panama: e.g. Pselliophorus spp., Pyrrhura hoffmani, Parula gutturalis and Troglodytes ochraceus, among others.

(2) Northern Central America and northern Chiapas: Lampornis sybillae, Otus barbarus and Cyanocorax melanocyaneus.

(3) Southern Chiapas: (Tangara cabanisi) and (Oreophasis derbianus).

(4) Eastern Mexico north of the Isthmus of Tehuantepec: Dendrortyx barbatus, (Cyanolyca nana) and (Rhynchopsitta terrisi).

(5) Sierra Madre del Sur: Eupherusa poliocerca, E. cyanophrys, Cyanolyca mirabilis, (Nyctiphrynus mcleodii) and (Cypseloides storeri).

(6) Interior Oaxaca: (Cyanolyca nana).

(7) Transvolcanic Belt and Sierra Madre Occidental: Cyanocorax dickeyi, Thalurania ridgwayi, (Streptoprocne semicollaris), (Rhynchopsitta pachyrhyncha), (Cardellina rubrifrons) and (Atlapetes virenticeps).

Each of these regions is faunistically distinctive from other such regions.

Of great interest to biogeographers is the historical pattern of interconnections among areas. This pattern could be represented as a tree showing the history of connection and isolation of different forest patches. The hierarchical pattern of similarity resulting from these analyses is as follows: (Costa Rica and western Panama, ((eastern Mexico, (northern Central America and Chiapas, southern Chiapas)), (Transvolcanic Belt and Sierra Madre Occidental, (Sierra Madre del Sur, interior Oaxaca))) (Figure 4). Although this pattern was detected by phenetic analyses, to the degree that avifaunal similarity reflects historical relationship, we can take it as a preliminary hypothesis of historical relationships among cloud-forest areas for later testing based on phylogenetic studies.

\section{Endemism and speciation}

By inspecting patterns of distribution of endemic species, regions that may be foci of differentiation and speciation may be identified. For example, the Costa Rica and western Panama area has many endemic species that appear to have 
differentiated and speciated in situ. Other areas that represent potential foci of differentiation and speciation include the Los Tuxtlas region of south-eastern Veracruz and the Sierra Madre del Sur of Guerrero and Oaxaca. Detailed phylogenetic studies of individual taxa are needed to clarify the historical processes that underlie these distributional patterns.

Although the high endemism in the Costa Rica/Panama area has been well appreciated (Wetmore 1965-1984, Stiles and Skutch 1989, ICBP 1992), elevated endemism in the two Mexican regions has gone relatively underappreciated (but see ICBP 1992, Long 1995). In 1988-1989, when three of us wrote a summary of patterns of avian diversity in Mexico (Escalante-Pliego et al. 1993), we knew of but one species endemic to the Los Tuxtlas region, the hummingbird Campylopterus excellens. Since that time, however, we have come to appreciate the distinctiveness of three other taxa: the quail-dove Geotrygon carrikeri, which is recognizable as a species separate from the southern G. lawrencii based on characters of plumage and morphology (Peterson 1993); the bush-tanager Chlorospingus [ophthalmicus] wetmorei, which is distinctive in genetic characters (Peterson et al. 1992); and the brush-finch Atlapetes [brunneinucha] apertus, which is readily distinguishable on the basis of plumage characters. Recognition of these forms as separate species of course depends on the species concept used; nevertheless, they are diagnosable forms and represent units of biological diversity distinct from other populations currently placed in the same species. Hence, the Los Tuxtlas region actually holds a number of endemic taxa, although the first impression was to the contrary; assessment of its importance as a centre of endemism if all near-species-level differentiates were recognized, however, must await future analyses (Navarro-Sigüenza and Peterson in prep.).

The Sierra Madre del Sur of Guerrero and Oaxaca (in some taxa extending north-west to Michoacán, Jalisco and Nayarit) is still more striking in its richness of endemic species, the distinctiveness of many of which has also been underappreciated. Taxa occurring in humid montane forests in the region include the newly described swift Cypseloides storeri (Navarro-Sigüenza et al. 1992), the hermit hummingbird Phaethornis [superciliosus] mexicanus (R. C. Banks pers. comm.), the extremely rare hummingbird Lophornis brachylopha (Banks 1990), the hummingbirds Thalurania ridgwayi (Jalisco and Nayarit only: Escalante-Pliego and Peterson 1992), Eupherusa poliocerca*, E. cyanophrys ${ }^{*}$, and Lampornis [amethystinus] margaritae (Torres-Chávez et al. in prep.), the toucanet Aulacorhynchus [prasinus] wagleri (Benítez-Díaz et al. in prep.), the woodpecker Piculus auricularis* (Baptista 1978), the antpitta Grallaria [guatimalensis] ochraceiventris (Peterson et al. in prep.), the jays Cyanolyca mirabilis* and Aphelocoma [unicolor] guerrerensis (Peterson 1992), and the bush-tanager Chlorospingus [ophthalmicus] albifrons (asterisks indicate recognition by AOU 1983). Hence, of the 13 species or nearspecies-level differentiates in humid montane forests in the region, only four were fully recognized by the AOU (1983). The majority are presently under study by ourselves and our students, based on a variety of morphological characters, investigations that are revealing more striking levels of endemism than previously appreciated (Peterson and Navarro-Sigüienza in prep.). The importance of the mountains of western Mexico as a centre of avian endemism has also been pointed out by ICBP (1992) and Long (1995).

Viewed more generally, in the context of the question posed in the Introduction, the surprising biological diversity of the humid montane forests of 
Mesoamerica has a complicated history. Some taxa have clearly entered the region from north or south (see examples in Introduction), but fully tor of the 335 species (30.1\%) seem to have speciated in situ in Mesoamerican humid montane forests. Hence, all three general explanations may have played important roles in the diversification of the birds of the humid montane forests of Mesoamerica (Escalante-Pliego et al. 1993).

\section{Priorities for conservation action}

An important reason for conducting studies such as this is to aid the design of optimal strategies for conserving biological diversity. In the present case, the avifaunas of humid montane forests are in trouble because the habitat is increasingly endangered. Humid montane forests are cleared for lumber and paper pulp interests, planting coffee, corn, and other agricultural products, or for grazing cattle or goats. In some cases, the destruction is absolute (e.g. clearcutting of forests); in other cases, it is gradual, such as through the grazing of cattle within forests, which causes a slow degradation of forest quality. The end result, however, is much the same: a place uninhabitable by animals and plants requiring native forest cover.

Given that money and opportunities for conservation action are limited, careful design of a strategy for conserving maximally the biological diversity of these forests is critical. A common approach is to focus on species of particular interest: for the present study, candidates might include the Horned Guan Oreophasis derbianus and Resplendent Quetzal Pharomachrus mocinno, both of which are large, attractive, endangered, and endemic to Mesoamerican humid montane forest. Nevertheless, as we have demonstrated in these analyses, the set of species potentially threatened in Mesoamerican humid montane forests is much more inclusive, and we therefore believe that efforts to preserve maximally the biological diversity of the region must instead be focused at the level of communities.

An exciting result that has emerged in the past decade is the remarkable coincidence in patterns of diversity and endemism among different taxonomic groups in Mesoamerica (see, e.g., Peterson et al. 1993. Ramamoorthy et al. 1993, Vázquez-García 1995). Patterns being concordant among many taxa, optimal conservation strategies should also generally coincide, because endemic forms are concentrated in the same areas. Given that birds are such a well-known group in terms of distribution and diversity, analyses of patterns of avian diversity are critical to the establishment of conservation priorities. The biogeographic regions delimited above are a good first step. Viable reserves should be established in each of the seven regions: (1) Costa Rica and western Panama, (2) northern Central America and northern Chiapas, (3) southern Chiapas, (4) eastern Mexico north of the Isthmus of Tehuantepec, (5) Sierra Madre del Sur, (6) interior Oaxaca, and (7) Transvolcanic Belt and Sierra Madre Occidental. Preservation of examples of each of these regions would protect the great majority of endemic montane forest birds in Mesoamerica.

Unfortunately, not all seven areas are currently under protection. Those areas that are currently protected more or less adequately (i.e. excluding areas under decree as protected areas but not in actuality receiving any protection) are (1) 
Costa Rica and western Panama (e.g. Parque Nacional La Amistad), (2) northern Central America and northern Chiapas (e.g. Parque Nacional Lagunas de Montebello), (3) southern Chiapas (Reserva de la Biósfera El Triunfo), and (7) Transvolcanic Belt (e.g. Parque Nacional Pico de Tancítaro, Parque Nacional Lagunas de Zempoala) and Sierra Madre Occidental (e.g. Reserva de la Biósfera "Sierra de Manantlán"). The remaining areas - (4), (5) and (6) - remain completely unprotected. We list (4) as unprotected in spite of the existence of the Reserva de la Biósfera "El Cielo" in Tamaulipas, because that mountain range is too far north to hold many of the species characteristic of that region.

Focusing on the 101 bird species endemic to Mesoamerican humid montane forests, the existing reserve system misses completely seven of these species: Cyanocorax dickeyi of the Sierra Madre Occidental of Sinaloa and Durango; the Bearded Wood-partridge Dendrortyx barbatus of Hidalgo, San Luis Potosí and northern Puebla and Veracruz; the Dwarf Jay Cyanolyca nana presently restricted to Cerro San Felipe of central Oaxaca; the Blue-capped Hummingbird Eupherusa cyanophrys of the Sierra de Miahuatlán of southern Oaxaca; the White-tailed Hummingbird E. poliocerca; the White-throated Jay Cyanolyca mirabilis of the Sierra Madre del Sur of Guerrero and Oaxaca; and the Green-breasted Mountain-gem Lampornis sybillae of Nicaragua and Honduras. Five of these species Dendrortyx barbatus, Cyanolyca nana, C. mirabilis, Eupherusa cyanophrys, and E. poliocerca - have already been identified as threatened with global extinction (Collar et al. 1992). Hence, clear priorities in the situation of new reserves include these areas, especially the Sierra Madre del Sur of Guerrero and Oaxaca, where three of these species remain unprotected (not to mention 10 additional forms presently under study, as mentioned above).

An ideal, if perhaps impractical, plan for the conservation of humid montane forest avifaunas would be the establishment of protected areas in each forest island, given that avifaunas of different islands within regions, although similar, are not identical. For areas in which political instability is a concern, binational protected areas may potentially buffer unique habitats against the whims of human matters (consider, for example, the destruction of forest areas in northern Chiapas in 1994 and 1995). More than anything, conservation of montane forest areas in Mesoamerica must adopt a two-pronged approach: (1) emergency protection of even the smallest patches of forest in critically endangered areas (e.g. forests in north-eastern Mexico, which are threatened with total eradication), and (2) identification and protection of the largest and most complete areas, which may permit the long-term preservation of entire ecosystems without substantial losses due to area effects (e.g. Sierra de Juárez, Oaxaca, where $300,000+$ ha of montane forest remain almost untouched). Our hope is that information and analyses presented herein will serve to focus such efforts more precisely, and allow conservation planners to make optimal use of their resources. We can make available electronic copies of the data matrix so as to permit further analysis and interpretation of the information presented herein.

\section{Acknowledgements}

We thank a great many people for their help with this project over the past 14 years. First and foremost, thanks to our many students who in the course of 
their studies have dedicated hundreds of hours to the work in field, library, museum, and laboratory needed to assemble this database. We thank our dear friends, Claudia Abad de Navarro, Carlos Cordero, Livia León-Paniagua, and Rosa M. Salazar for their friendship, help, and encouragement during this project. Several colleagues have offered helpful comments on the manuscript, including Mark Robbins, Oliver Komar and an anonymous reviewer. For access to specimens, we thank the curators of the Field Museum of Natural History, American Museum of Natural History, and University of Michigan Museum of Zoology. Funding was provided by the National Geographic Society, National Science Foundation, Dirección General de Asuntos del Personal Académico, CONACyT, PADEP, and the Field Museum of Natural History.

\section{Appendix 1. Summary of known distributions of birds in patches of humid montane forest in Mesoamerica.}

For each patch, occurrence of species is indicated as o, absent; $x$, not definitely known to occur, but likely on biogeographic grounds; and 1, definitely occurs. " $\mathrm{HAB}^{\prime \prime}=$ habitat use: $\mathrm{A}$, occurs in habitats above humid montane forests; and $B$, occurs in habitats below humid montane forests. "GEO" = extent of geographic range: $N$, occurs farther north than the northern limit of humid montane tropical forests as defined for the purposes of this paper; and S, occurs south or east of the Isthmus of Panama. "TV Belt" = the Transvolcanic Belt of central Mexico. Forest islands are numbered as in Appendix 2.

\begin{tabular}{|c|c|c|c|c|c|c|c|c|}
\hline & & & & & \multicolumn{3}{|c|}{ Mexico } & \multirow{3}{*}{ Central America } \\
\hline & \multirow{2}{*}{\multicolumn{2}{|c|}{$\frac{\mathrm{HAB}}{\mathrm{AB}}$}} & \multirow{2}{*}{\multicolumn{2}{|c|}{$\frac{G E O}{N S}$}} & East slope & West slope & TV Belt & \\
\hline & & & & & & & & \\
\hline Abeillia abeillei & 0 & 0 & 0 & 0 & $0010010 \times 1 x$ & $00000011 X$ & 0000 & $1 \times \times 1100000$ \\
\hline Acanthitops bairdii & 0 & 0 & o & 0 & 0000000000 & 000000000 & 0000 & 00000011111 \\
\hline Accipiter bicolor & o & 1 & 0 & 1 & 0000000000 & 000000000 & 0000 & $1 \times \times \times \times 1111: 1$ \\
\hline Accipiter gentilis & $\mathbf{I}$ & 0 & I & 0 & 0100000000 & 100100000 & 0000 & 0000000000 \\
\hline Accipiter striatus & I & 0 & 1 & 1 & $x y 0000100 x$ & 010100111 & 1000 & 1111100000 \\
\hline Aegolius acadicus & $\mathbf{I}$ & 0 & I & 0 & $0010001 \times 00$ & $0 \times 0000100$ & 1001 & 0000000000 \\
\hline Atgolius ritganayi & 0 & 0 & 0 & 0 & 0000000000 & 000000001 & 0000 & $1 \times \times 10000111$ \\
\hline Aeronautes saxatalis & 1 & 0 & 1 & $\mathrm{o}$ & $\times 1 \times 0000000$ & $\times 01100001$ & 1010 & $1 \times 1 \times 1000000$ \\
\hline Amaurospiaa concolor & 0 & 0 & 0 & 1 & $0000000 \times 00$ & 010101010 & 0000 & 00001111111011 \\
\hline Amazilia beryllina & I & I & 0 & 0 & $001 X \begin{array}{llllll} & 0 & 1 & 1 & 1 & X\end{array}$ & $x$ I I $7 x=0 x$ & 1 I I $x$ & $1 \times 11000000$ \\
\hline Amazilia candida & 0 & I & 0 & 0 & $\begin{array}{llllllllll}0 & I & I & 1 & 0 & 1 & 0 & X & 1 & 1\end{array}$ & $000000 \times 00$ & 0000 & $1 \times \times 1000000$ \\
\hline Anazilia cyanocephata & 1 & 1 & 0 & 0 & $111 \times 01111 x$ & $0000001 \times x$ & 0000 & 1111100000 \\
\hline Amazilia tzacatl & 0 & 1 & 0 & 1 & $1 \times \times 1 \times 1 \times \times \times \times$ & $000000 x \times x$ & 0000 & 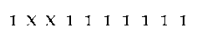 \\
\hline Amnzona tinschi & 0 & 1 & 0 & 0 & 0000000000 & $\times x \times x 11000$ & 0000 & 0000000000 \\
\hline Anabacerthia waricgaticens & 0 & 1 & 0 & 1 & $00010101 \times 1$ & $0001 \times 1111$ & 0000 & $\begin{array}{lllllllllll}1 & 1 & 1 & 1 & X & 1 & 1 & 1 & 1 & 1\end{array}$ \\
\hline Aphelocoma coerulescens & 1 & 0 & 1 & 0 & 0000101000 & 000000000 & 0011 & 0000000000 \\
\hline Aphelocoma altramarina & 1 & 0 & 1 & 0 & 1100000000 & 010000000 & $111 \times$ & 0000000000 \\
\hline Aphelocoma whicolor & 0 & 0 & 0 & 0 & 0111000100111 & 000100011 & 0000 & 1111000000 \\
\hline Aratinga holochlora & I & 0 & 1 & 0 & 11 I $\times \times \times \times \times \times \times$ & $x \times x \times x \times 000$ & 0000 & $1 \times \times 1100000$ \\
\hline Aratinga strentia & 0 & 1 & 0 & 0 & 0000000000 & $0000001 \times x$ & 0000 & $1001 \times 00000$ \\
\hline Asio stygins & 0 & 1 & 0 & I & 0010000000 & $\times 10100001$ & 0000 & $x \times x \times 00000$ \\
\hline Aspatin gularis & 0 & 0 & 0 & 0 & $000000001 x$ & 000000111 & 0000 & 1111000000 \\
\hline Athpetes albinucha & 0 & 0 & 0 & 0 & $0 \times 100101011$ & 000000000 & 0000 & 0000000000 \\
\hline Atlapetes brumeinucha & 0 & 0 & 0 & 1 & $\begin{array}{lllllllllll}1 & 1 & 1 & 1 & 1 & 1 & 1 & 1 & 1 & 1\end{array}$ & 000011111111 & 0000 & $11111 \times 11111$ \\
\hline Atlapetes gutturalis & o & 0 & $o$ & 1 & 0000000000 & 000000011 & 0000 & 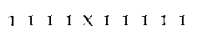 \\
\hline Atlapetes pileatus & 1 & 0 & $\mathrm{I}$ & 0 & $1110 \times \times 1100$ & $1111 \times 1000$ & I I I X & 0000000000 \\
\hline Atlapetes a'irenticeps & $i$ & 0 & 1 & 0 & 0000000000 & $x_{1} I 000000$ & $111 x$ & 0000000000 \\
\hline Atthis ellioti & 0 & 0 & 0 & 0 & 0000000001 & $00000001 x$ & 0000 & $11 \times 1000000$ \\
\hline Atthis heloisa & 1 & 0 & 0 & 0 & $1 \times 10111100$ & $x 11111000$ & $x \neq 1 x$ & 0000000000 \\
\hline Attila spadicens & 0 & 1 & 0 & 1 & $00110 \times 0 \times x \times$ & $\times \times 11 \times \times \times \times x$ & $11 \times \times$ & $1 X 111111711 X$ \\
\hline
\end{tabular}


Appendix 1 (cont.)

\begin{tabular}{|c|c|c|c|c|c|c|c|c|}
\hline & & & & & \multicolumn{3}{|c|}{ Mexico } & \multirow[b]{2}{*}{ Central America } \\
\hline & \multicolumn{2}{|c|}{$\mathrm{HAB}$} & \multicolumn{2}{|c|}{ GEO } & East slope & West slope & TV Belt & \\
\hline & & $\mathrm{B}$ & N & $S$ & & & & \\
\hline Aulacorhynchus prasmus & 0 & o & o & 0 & $0111010 \times 1 \times$ & 001111111 & 0000 & $\begin{array}{llllllllll}1 & 1 & 1 & 1 & 1 & 1 & 1 & 1 & 1 & 1\end{array}$ \\
\hline Automolus ochralaemus & 0 & 1 & o & 1 & $0011 \times 1 \times \times \times \times$ & 000000000 & 0000 & $1 \times \times \times 111111111$ \\
\hline Automolus rubigmosus & o & 0 & 0 & 1 & $0 \times 100101 \times x$ & 000111011 & 0000 & $1111 \times 00011$ \\
\hline Basileuterus belli & 1 & 0 & 0 & 0 & $111101111 \times$ & $11111111 \times$ & $110 x$ & 1111000000 \\
\hline Basileuterus culicicorus & 0 & 1 & 0 & 1 & $\begin{array}{lllllllll}1 & 1 & 1 & 1 & 0 & 1 & 0 & 1 \times \times\end{array}$ & $01 \times 1111 \times \times$ & 0000 & 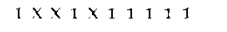 \\
\hline Basilenterus melanogenys & 0 & 0 & 0 & 0 & 0000000000 & 000000000 & 0000 & 0000000111 \\
\hline Basileuterus tristriatus & o & 1 & 0 & 1 & 0000000000 & 000000000 & 0000 & 0000001111 \\
\hline Bolborinunchus lineola & o & 0 & 0 & 1 & $0010010 \times 1 \times$ & $000 \times 0001 x$ & 0000 & $1 \times \times 1 \times 11111$ \\
\hline Buteo jamaicensis & 1 & 1 & 1 & 1 & $111 \times \times \times \times 1 \times \times$ & $\times 111 \times \times 11 \times$ & $1 \times 1 \times 1$ & $11 \times X 111111111$ \\
\hline Campephilus guatimalensis & 0 & 1 & 0 & 0 & $1111010 x 1 x$ & $x \times 11 \times \times 1 \times x$ & 1000 & 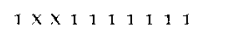 \\
\hline Camplylopterus curcipennis & o & 1 & 0 & o & $11100101 \times x$ & 000000000 & 0000 & $\times \times \times 1000000$ \\
\hline Campylopterus excellens & 0 & 1 & 0 & o & 0001000000 & 000000000 & 0000 & 0000000000 \\
\hline Campylopterus hemileucurus & 0 & 1 & 0 & 0 & $00110101 \times x$ & 000100111 & 0000 & 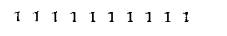 \\
\hline Campylopterus rutus & o & 0 & o & 0 & $00000000 \times x$ & $00000011 x$ & 0000 & $1 \times \times 1000000$ \\
\hline $\begin{array}{l}\text { Campylorhamphus pusillus } \\
\text { Campylorhynchus }\end{array}$ & 0 & 1 & o & 1 & 0000000000 & 000000000 & 0000 & 0000001111 \\
\hline megalopterus & 1 & o & 0 & 0 & 0010011100 & 011000000 & 1110 & 0000000000 \\
\hline Campylorhynchus zonatus & o & 1 & 0 & 1 & $0111010 \times 11$ & $0000001 \times 1$ & 0000 & $\begin{array}{lllllllllll}1 & 1 & 1 & 1 & 1 & 1 & 1 & 1 & 1 & 1\end{array}$ \\
\hline Caprimulgus ridgzuali & 0 & 1 & 1 & o & 0000000000 & $x 1 \times x \times 1 \times x \times$ & $\times 000$ & $x \times \times 1 \times 00000$ \\
\hline Caprimulgus saturntus & o & o & o & 0 & 0000000000 & 000000000 & 0000 & 0000001111 \\
\hline Caprimulgus rociferus & 1 & 1 & 1 & 0 & $X \times 1 \times 1 \times 1 \quad I X \times 1$ & $x=11 I I I 1 I X X$ & I $11 X$ & 1111000000 \\
\hline Cardellina rubrifrons & 1 & 0 & 1 & 0 & 0000000000 & 100000000 & 0000 & 0000000000 \\
\hline Carduelis atriceps & 1 & 0 & 0 & o & $000000001 \times$ & $0000000 \times x$ & 0000 & $1 \times 00000000$ \\
\hline Carduelis notata & 1 & 0 & 1 & 0 & $11101011 \times x$ & $\begin{array}{llllllll}1 & 1 & 1 & 1 & 1 & 1 & 1\end{array}$ & $111 \times$ & 1111100000 \\
\hline Carduelis pinus & 1 & 0 & 1 & 0 & $0 \times 1000001 x$ & $\times \times 0000000$ & $x \times 01$ & $0 \times 00000000$ \\
\hline Cardatis xanthogastra & 0 & o & 0 & 1 & 0000000000 & 000000000 & 0000 & 0000000111 \\
\hline Catharus aurantiirostris & 0 & 1 & 0 & 1 & $x 11000111 \times x$ & $\begin{array}{lllllllll}1 & 1 & 1 & 1 & 1 & 1 & 1 & X & 1\end{array}$ & $x 1 \times x$ & $1 \times \times 1$ Y $\times 1101$ \\
\hline Catharus dryas & o & 0 & 0 & $\mathbf{I}$ & 0000000000 & 000000111 & 0000 & 1111000000 \\
\hline Catharis frantzii & 0 & 0 & 0 & o & $001001111 \times$ & 0101011111 & 1000 & $\begin{array}{lllllllllll}1 & 1 & I & 1 & X & 1 & 1 & 1 & 1 & 1\end{array}$ \\
\hline Catharus fuscater & 0 & 0 & 0 & $\mathbf{I}$ & 0000000000 & 000000000 & 0000 & 0000011111 \\
\hline Catharus gracilirostris & 0 & 0 & 0 & 0 & 0000000000 & 000000000 & 0000 & 0000000111 \\
\hline Catharus mexicanus & 0 & 0 & $o$ & 0 & $111101001 x$ & $0000001 \times x$ & 0000 & $X 1111 \times 1 X 111111$ \\
\hline Catharus occidentalis & 1 & 0 & 1 & 0 & 0010011100 & 011111000 & $111 \times$ & 0000000000 \\
\hline Catherpes mexicamus & 1 & 0 & 1 & 0 & $111 \times \times \times \times \times \times 0$ & $x \times 1 \times \times \times 000$ & $x \times x \times$ & 0000000000 \\
\hline Certhia familiaris & 1 & 0 & 1 & 0 & $x \times x \quad 01111 \times 1 \times$ & $1 \times 11010 \times 1$ & $1 \times 1 \times 1$ & 1111100000 \\
\hline Chaetura tauxi & 0 & 1 & 1 & I & $11 \times 1 \times \times \times \times 1 \times$ & $1113 \times 11 \times x$ & $x \times x \times$ & $\begin{array}{llllllllll}1 & 1 & 1 & 7 & \times & 1 & 1 & 1 & 1 & 1\end{array}$ \\
\hline Chamaepetes unicolor & 0 & 0 & 0 & 0 & 0000000000 & 000000000 & 0000 & $0000010 I I I I I$ \\
\hline Chlorophonta callophrys & 0 & 0 & 0 & o & 0000000000 & 000000000 & 0000 & 00000111111 \\
\hline Chlorophonia occipitalis & 0 & 0 & 0 & ० & $0011010 \times 1 \times$ & 000000111 & 0000 & $1 \times \times 1100000$ \\
\hline Chlorospingus canigularis & 0 & o & o & I & 0000000000 & 000000000 & 0000 & 0000000101 \\
\hline Chlorospingus ophthaimicus & 0 & 0 & 0 & 1 & 01110010111 & 000111111 & 0000 & $1111 \times 111111$ \\
\hline Chlorospingus pileatus & 0 & 0 & 0 & 0 & 0000000000 & 000000000 & 0000 & 0000000111 \\
\hline Ciccaba airgata & 0 & 1 & 0 & 1 & $1111 \times x \times x \times x$ & $1 \times \times 1 \times \times \times x \times$ & $0 \times 10$ & $111 \times 111111111$ \\
\hline Cincius mexicanus & 1 & 0 & 1 & 0 & $0010001 \times 00$ & $x \times x 101000$ & 1100 & 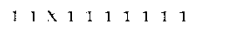 \\
\hline Clarawis mondetoura & o & 0 & 0 & I & 0110000000 & 000000001 & 0000 & $1 \times X 11 \times X 11111$ \\
\hline Coccothraustes abeillei & 0 & 0 & 0 & 0 & $111 \times 010 \times \times 1$ & $\times 1 \times 100001011$ & $x \times 10$ & 1 I I 1000000 \\
\hline Coccothraustes tespertinus & 1 & 0 & 1 & 0 & $0 \times 10001000$ & $\times x \times 000000$ & $x \times 00$ & 0000000000 \\
\hline Colaptes auratus & 1 & 0 & 1 & 0 & $x y 1 \times 11111 x$ & $x \times 11$ y $1 \times x x$ & $x \times 1 \times$ & 1111000000 \\
\hline Colibri delphinae & 0 & 1 & 0 & 1 & 0000000000 & 000000000 & 0000 & $00 \times 1 \times 1 \times 11111$ \\
\hline Colibri thalassinus & 0 & 1 & $\circ$ & 1 & $01 \times 0111$ y $1 \times$ & $0 \times 1101111 \times$ & $\begin{array}{llll}1 & 1 & 1 & 0\end{array}$ & $11 \times 1 \times \times 1111$ \\
\hline Columba fascinta & 1 & o & 1 & T & $x \times x O 0111 \times 1 \times$ & $x 1111111 X$ & $x \times x \times$ & $\begin{array}{lllllllllll}1 & 1 & 1 & 1 & 1 & 1 & 1 & 1 & 1 & 1\end{array}$ \\
\hline Columbo subrinacea & 0 & I & 0 & 1 & 0000000000 & 000000000 & 0000 & 0000001111 \\
\hline Contopus lugubris & 0 & 0 & 0 & 0 & 0000000000 & 000000000 & 0000 & $0 \begin{array}{llllllllllllllllllllllll}0 & 0 & 0 & 0 & 1 & 1 & 1 & 1\end{array}$ \\
\hline Contopus ochracens & 0 & 0 & 0 & 0 & 0000000000 & 000000000 & 0000 & 0000000111 \\
\hline Contopus pertimax & 1 & o & 1 & 0 & $1110111 \times \times \times$ & $1111111 \times x$ & $11 \times x$ & 1191100000 \\
\hline Cotinga amabilis & 0 & 1 & 0 & 0 & $0001010 \times x \times$ & 000000000 & 0000 & $x \times x 1 \times 1 \times 1110$ \\
\hline Cotinga ridgunyi & o & 1 & $o$ & 0 & 0000000000 & 000000000 & 0000 & 0000000011 \\
\hline Cranioleuca erythrops & 0 & 0 & $\circ$ & 1 & 0000000000 & 000000000 & 0000 & 000001111111 \\
\hline Crax rubra & $o$ & 1 & 0 & 1 & $x \times x+x 1 \times x \times x$ & $0000001 \times x$ & 0000 & 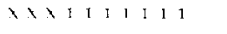 \\
\hline
\end{tabular}


Appendix 1 (cont.)

\begin{tabular}{|c|c|c|c|c|c|c|c|c|}
\hline & \multicolumn{7}{|c|}{ Mexico } & \multirow{3}{*}{ Central America } \\
\hline & \multicolumn{2}{|c|}{$\mathrm{HAB}$} & \multicolumn{2}{|c|}{ GEO } & East slope & West slope & TV Belt & \\
\hline & \multicolumn{2}{|c|}{ A B } & \multicolumn{5}{|c|}{ NS } & \\
\hline Cryptirellus inmanometis & 0 & 1 & 0 & 0 & $111100 \times x \times x$ & $1 \times \times 1 \times \times 11 \times$ & 0000 & $1 \times 1 \times 1110001$ \\
\hline Cyanerpes cyaneus & 0 & 1 & 0 & 1 & $0 \times x 1010 \times x \times$ & 000000000 & 0000 & $1 \times 1111111111 \times$ \\
\hline Cuanocitta stelleri & 1 & 0 & 1 & 0 & $0 \times 101111 I X$ & $1 \times 11110 \times 1$ & $1 \times \times \times$ & $11 \times 1100000$ \\
\hline Cuanocompsa parellina & 0 & I & 0 & 0 & I I I I $00001 \times x$ & $X \times X \times I I I X I$ & 0000 & $x \times x 1100000$ \\
\hline Cyanoconax dickeyi & 0 & 0 & 0 & 0 & 0000000000 & 100000000 & 0000 & 0000000000 \\
\hline Cyanocorax melanocyanteus & 0 & 0 & 0 & 0 & 0000000000 & 000000000 & 0000 & $1 \times 11100000$ \\
\hline Cyanocorax yncas & o & 1 & 0 & 1 & $11110 \times 0 \times 11$ & OI $11 \times 111 \times$ & 0000 & $1 \times \times 1000000$ \\
\hline Cyanolyca argentigula & 0 & 0 & 0 & 0 & 0000000000 & 000000000 & 0000 & 0000000111 \\
\hline Cyanolyca cucullata & 0 & 0 & 0 & 0 & 0110010111 & 000000111 & 0000 & 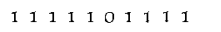 \\
\hline Cyanolyca mirabilis & o & 0 & $o$ & 0 & 0000000000 & 000111000 & 0000 & 0000000000 \\
\hline Cyanolyca nana & 0 & 0 & 0 & 0 & 0010011100 & 000000000 & 0000 & 0000000000 \\
\hline Cyanolyca pumilo & 0 & 0 & 0 & 0 & 0000000011 & 000000011 & 0000 & 1111000000 \\
\hline Cyclarlis guianensis & 0 & 1 & 0 & 1 & I $1110 x O x I X$ & $0000001 \times x$ & 0000 & $I \times X \times 11 \times X I 11 I I$ \\
\hline Cypseloides cherriei & 0 & 0 & 0 & 1 & 0000000000 & 000000000 & 0000 & $000000011 \times$ \\
\hline Cypseloides cryptus & o & 0 & o & 1 & 0000000000 & 000000000 & 0000 & $000 \times 01111 \times$ \\
\hline Cypseloides niger & 0 & 0 & 1 & 0 & 0010011000 & $x \times x 0010 \times x$ & $x 00 x$ & $x \times x 1 \times x \times 11 \times$ \\
\hline Cupselotides rutins & 0 & 0 & $o$ & 1 & $001 \times 01011 \times$ & $x 100111 \times x$ & $0 \times 00$ & $x \times \times 1 \times \times \times 111$ \\
\hline Cipseloides storeri & 0 & 1 & 0 & 0 & 0000000000 & 000100000 & $\times 000$ & 0000000000 \\
\hline Dactylortyx thoracicus & 0 & 0 & 0 & ० & $1 \times 1 \times \times \times \times \times 1 \times$ & $01 \times 10011 \times$ & 0000 & $11 \times 1000000$ \\
\hline Dendrocincla anabatina & o & 1 & 0 & 0 & $01 \times 1010 \times \times \times$ & 000000000 & 0000 & $x \times 1110 \times x 11$ \\
\hline Dendrocincla homochrod & 0 & 1 & 0 & 1 & $00000101 \times x$ & $0000001 \times x$ & 0000 & $1 \times 1 \times 1 \times 1 \times 11$ \\
\hline Dendrocolaptes picummers & 0 & 1 & 0 & 1 & 0000000011 & 000000000 & 0000 & $\times \times 11 \times 00111$ \\
\hline Dendroica graciat & 1 & $o$ & 1 & 0 & $001010 \times 0 \times 1$ & $x \times 11111 \times 1$ & $x \times x \times$ & $1 \times 11100000$ \\
\hline Denul rortyx barbatus & 0 & 0 & 0 & $\mathrm{O}$ & 0110000000 & 000000000 & 0000 & 0000000000 \\
\hline Dendrortyx leucophrys & o & 0 & 0 & $\mathrm{o}$ & $000000001 x$ & $0000000 \times x$ & 0000 & $11 \times 1100110$ \\
\hline Dendrortyx macroura & o & 0 & 0 & 0 & 0010111100 & $01 \times 101000$ & 0100 & 0000000000 \\
\hline Diglossa baritula & I & 0 & 0 & 0 & $0 \times 1001111111 X$ & $01 \times 11 I I \times 1$ & $111 \times$ & $1 \times 1 \times 1000000$ \\
\hline Diglossa plumber & 0 & 0 & 0 & 0 & 0000000000 & 000000000 & 0000 & 0000011111 \\
\hline Doricha eliza & 0 & 1 & 0 & 0 & 0010000000 & 000000000 & 0000 & 0000000000 \\
\hline Doricha enicura & o & 0 & 0 & 0 & $00000000 \times x$ & $0000000 \times x$ & 0000 & $1 \times \times 1000000$ \\
\hline Doryfera ludoviciat & 0 & o & 0 & 1 & 0000000000 & 000000000 & 0000 & 0000001111 \\
\hline Dryocopus lineatus & 0 & 1 & 0 & 1 & $11 \times 1010 \times 1 \times$ & $x \times 1 \times \times \times 1 \times x$ & 0000 & 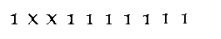 \\
\hline Dysithamuns mentalis & 0 & 1 & 0 & 1 & $000000000 x$ & 000000000 & 0000 & OOOIOI1111 \\
\hline Elaenia frantsit & o & 0 & 0 & 1 & 0000000000 & 000000000 & 0000 & 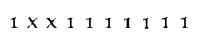 \\
\hline Electron carmatum & 0 & 0 & 0 & 0 & $000 \times 000000$ & 000000000 & 0000 & $0 \times \times 1111000$ \\
\hline Eltirn chionura & 0 & 0 & 0 & 0 & 0000000000 & 000000000 & 0000 & 0000000011 \\
\hline Elirira cupreiceps & o & 0 & 0 & 0 & 0000000000 & 000000000 & 0000 & 0000011100 \\
\hline Empidonax affinis & 1 & 0 & 0 & 0 & 0010011000 & $X 11101000$ & $\times 1 \times 1$ & 0000000000 \\
\hline Empidonax albigularis & 0 & 1 & 0 & 0 & $0111 \times \times \times 1 \times x$ & $1 \times \times \times \times \times \times \times 1$ & $x \times x \times$ & $1 \times X 1100101$ \\
\hline Empidonax atriceps & 0 & 0 & 0 & o & 0000000000 & 000000000 & 0000 & 0000000111 \\
\hline Empitomax difficils & 1 & 0 & 1 & 0 & I $110 \times 11100$ & $1111 \times 1000$ & I $11 X$ & 0000000000 \\
\hline Empidonax thasesens & o & 0 & 0 & 0 & 0001000011 & 000000111 & 0000 & $\begin{array}{llllllllll}1 & 1 & 1 & 1 & 1 & 1 & 1 & 1 & 1 & 1\end{array}$ \\
\hline Ergaticus ruber & 1 & 0 & I & 0 & $0 \times 10 \times 11100$ & $x: 1111000$ & $111 \times$ & 0000000000 \\
\hline Ergaticus itersicolor & 0 & 0 & 0 & 0 & 0000000011 & $0000000 \times 1$ & 0000 & 1110000000 \\
\hline Enbucco bourcierit & 0 & 1 & 0 & 1 & 0000000000 & 000000000 & 0000 & 0000001111 \\
\hline Eligentes fulgens & 1 & 0 & 1 & 0 & $111011111 \times$ & 111111111 & $111 \times$ & $1111 \times 00111$ \\
\hline Etuphertsa cyanophrys & 0 & 0 & 0 & 0 & 0000000000 & 000001000 & 0000 & 0000000000 \\
\hline Eupherusa eximia & o & 0 & 0 & $\mathrm{O}$ & $00 \times 0010 \times \times 1$ & $0000001 \times x$ & 0000 & 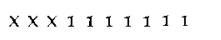 \\
\hline Eupherusit nigrientris & o & 0 & 0 & 0 & 0000000000 & 000000000 & 0000 & $00000001 \mathrm{II}$ \\
\hline Elupherasa poliocerca & 0 & 0 & 0 & 0 & 0000000000 & 000110000 & 0000 & 0000000000 \\
\hline Eliphonin annete & 0 & 1 & 0 & 1 & 0000000000 & 000000000 & 0000 & O00000IIIIII \\
\hline Euphonia elegantissma & 0 & 1 & 0 & 0 & $111 \times 111 \times 1 \times$ & $x 1 \times x I I I X x$ & $x I X x$ & $11 \times 1 \times \times \times 11 \times$ \\
\hline Ethowia hirmdinacen & o & $\mathfrak{i}$ & 0 & 0 & T11 $1010 \times \times \times$ & 000000000 & 0000 & 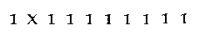 \\
\hline Formicarins analis & 0 & 1 & 0 & 1 & $0011010 \times 1 \times$ & 000000000 & 0000 & 0111111111 \\
\hline Formicarius rufipectus & 0 & 1 & 0 & 1 & 0000000000 & 000000000 & 0000 & 0000001111 \\
\hline Geothlypis nelsoni & 1 & 0 & 1 & 0 & $1110 \times 11100$ & 000011000 & 0101 & 0000000000 \\
\hline Geotrygon abitacies & 0 & 0 & 0 & 0 & $011001 \times 1 \times x$ & $00010111 \times$ & 0000 & 1111100000 \\
\hline Gootrygon chiriguensis & 0 & 0 & 0 & 0 & 0000000000 & 000000000 & 0000 & 0000011111 \\
\hline
\end{tabular}


Appendix 1 (cont.)

\begin{tabular}{|c|c|c|c|c|c|c|c|c|}
\hline & \multirow{2}{*}{\multicolumn{2}{|c|}{$\mathrm{HAB}$}} & \multirow{2}{*}{\multicolumn{2}{|c|}{$\mathrm{GEO}$}} & \multicolumn{3}{|c|}{ Mexico } & \multirow{3}{*}{ Central America } \\
\hline & & & & & East slope & West slope & TV Belt & \\
\hline & A & B & $\mathrm{N}$ & $\mathrm{S}$ & & & & \\
\hline Geotrygon costaricensis & 0 & 0 & 0 & $o$ & 0000000000 & 000000000 & 0000 & 00000111111 \\
\hline Geotrygon carrikeri & 0 & 0 & o & 1 & 0001000000 & 000000000 & 0000 & 0000000000 \\
\hline Geotrygon lawrencii & 0 & 0 & 0 & 0 & 0000000000 & 000000000 & 0000 & 0000011111 \\
\hline Glancidium groma & 1 & 0 & 1 & 0 & $x \times x 00110 \times x$ & $x 1111110 x x$ & $111 x$ & $x \times x 1000000$ \\
\hline Glaucidium jardinit & o & 0 & 0 & 1 & 0000000000 & 000000000 & 0000 & 0000000111 \\
\hline Glaucidium minutissimum & 0 & 1 & 0 & 1 & $1 \times \times \times 0 \times 01 \times x$ & $\times 1 \times 1 \times \times \times \times x$ & 0000 & $1 \times \times 1 \times \times \times 1 \times \times$ \\
\hline Grallaria guatimalensis & 0 & 0 & 0 & 1 & $0111001 \times x \times$ & $0 x \times 1111111 x$ & 0100 & $\begin{array}{lllllllllll}1 & 1 & 1 & 1 & X & 1 & 1 & 1 & 1 & 1\end{array}$ \\
\hline Habia fuscicauda & 0 & 1 & 0 & 1 & I I $111010 \times \times \times$ & 000000000 & 0000 & $0 \times x \times 11111111111$ \\
\hline Habia rubica & 0 & 1 & 0 & 1 & $1 \times 11010 \times \times \times$ & $01 \times \times \times \times x \times x$ & 0000 & $1 \times \times 1 \times 111 \times 1$ \\
\hline Haplospiza rustica & 0 & 0 & $o$ & 1 & 0010000000 & 000000001 & 0000 & 0001001111 \\
\hline Harpylaliaetus solitarius & 0 & 1 & 0 & $\mathbf{I}$ & 0000000000 & 000000100 & 0010 & $00 \times 10 \times \times 111$ \\
\hline Heliodora jacula & $o$ & 0 & 0 & 1 & 0000000000 & 000000000 & 0000 & 00000111111 \\
\hline Heliomaster longirostris & 0 & 1 & 0 & 1 & $0011010 \times x \times$ & $00010 I I X X$ & 0000 & $x 001 \times 11111$ \\
\hline Henicorhina leucophrys & 0 & 0 & 0 & $\mathrm{I}$ & 0110071111 & 011111111011 & 1000 & $\begin{array}{llllllllll}1 & 1 & 1 & X & 1 & 1 & 1 & 1 & 1\end{array}$ \\
\hline Henicorhina lencosticta & 0 & 1 & 0 & 1 & $01 \times 1010 \times \times \times$ & $0000001 \times x$ & 0000 & $\begin{array}{llllllllllll} & 1 & 1 & 1 & 1 & 1 & 1 & 1 & 1 & 1\end{array}$ \\
\hline Hylocharis lewcotis & 1 & 1 & 1 & 0 & $011011111 X$ & $x=171111+x 1$ & $111 x$ & 1111100000 \\
\hline Hylomanes momotula & 0 & 0 & $o$ & 1 & $0001010 \times x \times$ & $000000 \times x \times$ & 0000 & $1 \times 1 \times 1 \times 10001$ \\
\hline Icterus graduacauda & 1 & 1 & 1 & 0 & $11 \times 0110100$ & 011111000 & $0 \times 00$ & 0000000000 \\
\hline hanco phaeonotus & 1 & 0 & 1 & 0 & $X X 10001111$ I $X$ & $\begin{array}{lllllllll} & X & 1 & 1 & 1 & 1 & 0 & \times & 1\end{array}$ & 1101 & 1100000000 \\
\hline Lamponis amethystinus & 0 & 0 & 0 & 0 & $\begin{array}{llllllllll}1 & 1 & 1 & 1 & 1 & 1 & 1 & 1 & 1 & x\end{array}$ & 0111010101 & $111 \times$ & 1111000000 \\
\hline Lamponis calolaema & 0 & 0 & 0 & 0 & 0000000000 & 000000000 & 0000 & 0000011110 \\
\hline Lamponis cinereicauda & 0 & 0 & 0 & 0 & 0000000000 & 000000000 & 0000 & 0000000011 \\
\hline Lampornis castaneorentris & 0 & 0 & 0 & 0 & 0000000000 & 000000000 & 0000 & 0000000001 \\
\hline Lampornis demenciae & 0 & 1 & 1 & 0 & $x \times 10101 \times 00$ & $x \times 11110000$ & $\begin{array}{llll}1 & 1 & 1 & 1\end{array}$ & 0000000000 \\
\hline Lampornis sybillae & 0 & 0 & 0 & 0 & 0000000000 & 000000000 & 0000 & 0001100000 \\
\hline Lampornis hemileucus & 0 & 0 & 0 & $\mathrm{O}$ & 0000000000 & 000000000 & 0000 & $000000111 \times$ \\
\hline Lampornis ziridipallens & 0 & 0 & 0 & 0 & $000000001 x$ & 000000111 & 0000 & 1111000000 \\
\hline Lamprolaima rhami & 0 & 0 & 0 & 0 & OOXOIIIIIX & 000101011 & $0 \times 00$ & 1111000000 \\
\hline Lepidocolaptes affinis & 0 & 0 & 0 & 1 & $\begin{array}{llllllllll} & 1 & 1 & 1 & 1 & 1 & 1 & 1 & 1 & 1\end{array}$ & 000111111 & 0000 & $\begin{array}{lllllllllll}1 & 1 & 1 & 1 & X & 1 & 1 & 1 & 1 & 1\end{array}$ \\
\hline Lepidocolaptes leucogaster & 0 & 1 & 0 & 0 & $00 \times 0011000$ & $\times 11 \times 11000$ & $x 110$ & 0000000000 \\
\hline Leptopogon amaurocephalus & $\mathrm{O}$ & 1 & 0 & 1 & $0001010 \times \times x$ & 000000000 & 0000 & $X \times 1 \quad 1 \quad 1 \times 1111 \times 1$ \\
\hline Leptopogon superciliaris & 0 & 1 & 0 & 1 & 0000000000 & 000000000 & 0000 & 0000001111 \\
\hline Leptotila ierreauxi & 0 & 0 & 0 & 1 & $1111 \times \times 1 \times \times 1$ & $x \times 1 \times x \times 11 \times$ & $x \times 1 \times$ & $\begin{array}{lllllllllll}1 & X & X & I & 1 & I & 1 & 1 & 1 & 1\end{array}$ \\
\hline Leucopternis albicollis & 0 & 0 & o & 1 & $00 \times 10101 \times x$ & $000000 \times x \times$ & 0000 & $x \times x] 1+1] 111$ \\
\hline Leicopternis princeps & 0 & 0 & 0 & 1 & 0000000000 & 000000000 & 0000 & 00000111111 \\
\hline Lophostrix cristata & 0 & 1 & 0 & 1 & $00 \times x 0 \times 0 \times x \times$ & $0000 \times \times \times x \times$ & 0000 & $x \times x \perp x 11111$ \\
\hline Lophotriccus pileatus & 0 & 1 & 0 & 1 & 0000000000 & 000000000 & 0000 & 0000011111 \\
\hline Loxia curivostra & 1 & 0 & Y & 0 & $x \times x 010101 x$ & $1111011 \times x$ & $x \times x \times$ & $x \times x 1100000$ \\
\hline Lysuris crassirostris & 0 & o & 0 & 1 & 0000000000 & 000000000 & 0000 & 0000001131 \\
\hline Margaromis rubiginosus & 0 & 0 & 0 & 0 & 0000000000 & 000000000 & 0000 & 0000011111 \\
\hline Megarynchus pitangua & 0 & 1 & 0 & 1 & $1111 \times \times \times \times \times \times$ & $x \times x \times x 111 \times$ & $x \times x \times$ & $I X X \begin{array}{lllllllll} & X & 1 & 1 & 1 & 1 & 1 & 1\end{array}$ \\
\hline Melanerpes formicironus & 1 & 1 & 1 & 1 & I 11011 I $11 x$ & $x 1111111 x$ & $1+1 x$ & $\begin{array}{lllllllllll}1 & 1 & 1 & 1 & 1 & \times & 1 & 1 & 1 & 1\end{array}$ \\
\hline Melanotis coerulescens & 0 & 1 & 1 & 0 & 1110111100 & $\begin{array}{lllllllll}1 & 1 & 1 & 1 & 1 & 1 & 0 & 0 & 0\end{array}$ & 1 I $1 X$ & 0000000000 \\
\hline Melanot is hypolemens & 0 & 0 & 0 & 0 & 0000000011 & 000000011 & 0000 & $111 \times 000000$ \\
\hline Micrastur ruficollis & 0 & 1 & 0 & I & OIIIOIOXXX & $0010011 \times x$ & 0000 & $x \times 11 \times 111111$ \\
\hline Microcerculus marginatus & 0 & 1 & 0 & 1 & $00000000 \times 1$ & 000000000 & 0000 & $x \times \times 1 \times 1$ I $1 \times 1$ \\
\hline Mionectes oleagineus & 0 & $I$ & 0 & $\mathrm{I}$ & $0011010 \times \times x$ & 000000000 & 0000 & $11 \times 1 \times 1111 \times$ \\
\hline Mitrephanes phaeocercus & o & 0 & 0 & 1 & $11100111101 x$ & I $1111111 \times 1 \times$ & $1+1 x$ & $\begin{array}{lllllllllllllllll}1 & 1 & 1 & 1 & 1 & 1 & 1 & 1 & 1 & 1\end{array}$ \\
\hline Momotus momota & 0 & 1 & 0 & 1 & $1111010 \times \times \times$ & $0000001 x x$ & 0000 & $\begin{array}{llllllllll}1 & 1 & 1 & 1 & 1 & 1 & 1 & 1 & 1 & 1\end{array}$ \\
\hline Myadestes melanops & 0 & 0 & 0 & 0 & 0000000000 & 000000000 & 0000 & 0000011111 \\
\hline Myadestes occidentalis & 1 & o & 0 & 0 & $\begin{array}{lllllllll}1 & 1 & 0 & 1 & 1 & 1 & 1 & 1 & x\end{array}$ & $\begin{array}{llllllllll}1 & 1 & 1 & 1 & 1 & 1 & 1 & 1 & 1\end{array}$ & $111 X$ & 1111000000 \\
\hline Myadestes wicolor & $a$ & 0 & 0 & 0 & 0111010111 & 000000111 & 0000 & 0111100000 \\
\hline Myiarchus twberculiter & 1 & 1 & 1 & 1 & $1111011 \times 1 \times$ & $x \times 11111 \times x$ & $111 X$ & $\begin{array}{llllllllll}1 & 1 & 1 & 1 & 1 & 1 & 1 & 1 & X\end{array}$ \\
\hline Myohius sulphurepygits & 0 & 1 & 0 & 1 & $0011010 \times \times \times$ & 000000000 & 0000 & $X X X \begin{array}{llllllllll}X & X & 1 & 1 & 1 & 1 & 1 & 1\end{array}$ \\
\hline Myioborus miniatus & 1 & 0 & 1 & 1 & 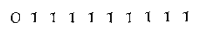 & $\begin{array}{llllllllll} & 1 & 1 & 1 & 1 & 1 & 1 & 1 & 1\end{array}$ & $111 x$ & $\begin{array}{lllllllllll}1 & 1 & 1 & 1 & X & 1 & 1 & 1 & 1 & 1\end{array}$ \\
\hline Myioborus pictus & 1 & 0 & 1 & 0 & $I] I X \times 1 \times X \times 11$ & $x 111 \times \times \times 11$ & $111 x$ & 1111100000 \\
\hline Myioborus torquatus & 0 & 0 & 0 & 0 & 0000000000 & 000000000 & 0000 & 0000001111 \\
\hline Myidynastes hemichrysens & 0 & 0 & 0 & 0 & 0000000000 & 000000000 & 0000 & 00000111111 \\
\hline
\end{tabular}


Appendix 1 (cont.)

\begin{tabular}{|c|c|c|c|c|c|c|c|c|}
\hline & & & & & & Mexico & & \\
\hline & & $\mathrm{AB}$ & & $\mathrm{EO}$ & East slope & West slope & TV Belt & Central America \\
\hline & A & $\mathrm{B}$ & $\mathrm{N}$ & & & & & \\
\hline Myiodynastes luteiventris & 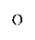 & 1 & 1 & o & $111 \times 0 \times 0 \times \times \times$ & $x \times x \times x \times 1 \times x$ & 0000 & $1 \times \times 1 \times 11100$ \\
\hline Myiopagis ziridicata & 0 & 1 & 0 & 1 & $x \times 11 \times 1 \times x \times x$ & $x 111 \times \times \times \times x$ & $x \perp 1 x$ & 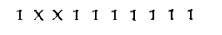 \\
\hline Myrmeciza immaculata & $o$ & 1 & 0 & 1 & 0000000000 & 000000000 & 0000 & 0000011111 \\
\hline Myrmotherula schisticolor & 0 & 1 & 0 & 1 & $00000000 \times 1$ & $0000000 \times 1$ & 0000 & $0 \times \times 1 \times 111111$ \\
\hline Nothocercus bonapartei & 0 & 1 & 0 & 1 & 0000000000 & 000000000 & 0000 & 0000010111 \\
\hline Nyctidromus albicollis & o & 1 & 1 & 1 & $1111 \times \times \times \times \times \times$ & $x 1 \times x \times x+1 x$ & $\times 0000$ & $\begin{array}{llllllllll}x & x & 1 & 1 & 1 & 1 & 1 & 1 & 1\end{array}$ \\
\hline Nyctiphrynus mcleodii & 0 & 1 & 0 & 0 & 0000000000 & 010001000 & 0000 & 0000000000 \\
\hline Odontophorus guttatus & o & o & 0 & 0 & $00 \times 10 \times 0 \times \times x$ & $0000001 \times x$ & 0000 & $1 \times X 11 \times \times 111$ \\
\hline Odontophorus lewcolaemus & 0 & 0 & 0 & o & 0000000000 & 000000000 & 0000 & 0000011111 \\
\hline Oreophasis derbianus & o & o & o & o & 0000000000 & 000000011 & 0000 & 1000000000 \\
\hline Otus barbarus & 0 & 0 & 0 & 0 & $00000000 \times \times$ & 000000000 & 0000 & 0100000000 \\
\hline Otus choliha & o & 1 & o & 1 & 0000000000 & 000000000 & 0000 & $0001 \times \times 1111$ \\
\hline Otus clarkii & o & o & o & 1 & 0000000000 & 000000000 & 0000 & 0000011111 \\
\hline Otus flammeolus & 1 & o & 1 & o & 0010000000 & 011100000 & $x+1 x$ & $x 000000000$ \\
\hline Otus guatemalae & o & 1 & 1 & 1 & $1 \times 1 \times \times \times \times \times 1 \times$ & $x \times 0000000$ & 0000 & $0 \times \times 1 \times I 1111$ \\
\hline Otus trichopsis & 1 & 0 & 1 & o & $x \times 10001000$ & $0 \times 1 \times 11000$ & $11 \times x$ & $11 \times 1000000$ \\
\hline Pachyramphus aglaiae & 0 & 1 & 1 & 0 & $1111 \times \times 1 \times \times x$ & $x 1 \times x \times x I 1 \times$ & $x$ I $1 x$ & $1 \times \times \times \times 10000$ \\
\hline Pachyramphus albogrisens & 0 & 1 & 0 & 1 & 0000000000 & 000000000 & 0000 & 0000001111 \\
\hline Pachyramphus major & a & o & 0 & o & $1111010 \times \times x$ & 111101111 & 0000 & 1111100000 \\
\hline Pachyramphus zersicolor & 0 & o & 0 & 1 & 0000000000 & 000000000 & 0000 & 0000001111 \\
\hline Panterpe insignis & 0 & 0 & o & 0 & 0000000000 & 000000000 & 0000 & 0000011111 \\
\hline Panyptila sanctihieronymi & o & 1 & 0 & 0 & 0000000000 & $001 \times 11110$ & xooo & $1 \times 1000000$ \\
\hline Paruia gutturalis & o & 0 & o & o & 0000000000 & 000000000 & 0000 & $00000001 \mathrm{TI}$ \\
\hline Parula pitiayumi & 0 & 1 & o & 1 & 1100000000 & $x \times 0100010$ & 0000 & $1 \times 11 \times 11111$ \\
\hline Parula superciliosa & 0 & o & 0 & o & $\begin{array}{llllllllll}1 & 1 & 1 & 0 & 1 & 1 & 1 & 1 & 1 & X\end{array}$ & $\begin{array}{lllllll}1 & 1 & 1 & 1 & 1 & X & 1\end{array}$ & $111 x$ & 1111100000 \\
\hline Parus sclateri & 1 & o & 1 & 0 & 0010011000 & $x \times 1101000$ & $11 \times 1$ & 0000000000 \\
\hline Penelope purpurascens & 0 & 1 & 0 & 1 & $11 \times 101011 \times$ & $11110111 X$ & 0000 & $x \times X I X I 1111$ \\
\hline Penelopina nigra & o & o & 0 & o & $000000001 \times$ & 000000111 & 0000 & $11 \times 1100000$ \\
\hline Peucedramus taeniatus & 1 & 0 & 1 & 0 & $1 \times 101110 \times x$ & $1 \times 11010 \times x$ & $1 \times 1$ & 1111100000 \\
\hline Pezopetes capitalis & 0 & 0 & 0 & o & 0000000000 & 000000000 & 0000 & 0000000111 \\
\hline Phaethornis guy & $o$ & 1 & 0 & 1 & 0000000000 & 000000000 & 0000 & 0000011111 \\
\hline Phaethornis longuemareus & 0 & 1 & o & $\mathrm{I}$ & $0011010 \times x \times$ & 000000000 & 0000 & 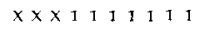 \\
\hline Phaethornis superciliosus & 0 & 1 & o & 1 & $00 \times 1010 \times \times x$ & $01 \times 111 \times x \times$ & 0000 & $x \times x \times 11111111$ \\
\hline Phainoptila melanoxantha & 0 & o & 0 & 0 & 0000000000 & 000000000 & 0000 & 0000011111 \\
\hline Pharomachrus mocimo & o & o & 0 & o & 0000000011 & $00000011 x$ & 0000 & $\begin{array}{lllllllllll}1 & 1 & 1 & 1 & 1 & 0 & 1 & 1 & 1 & 1\end{array}$ \\
\hline Pheucticus chrysopeplus & o & 1 & o & o & 0000000000 & $x \times \times 1 \times \times \times 11$ & $0 \times 00$ & $1 \times 00000000$ \\
\hline Pheucticus melanocephalus & o & 1 & 1 & o & $11 \times 0011 \times 00$ & $x \times 1111000$ & $111 x$ & 0000000000 \\
\hline Pheucticus tibialis & 0 & 0 & 0 & o & 0000000000 & 000000000 & 0000 & 0000011111 \\
\hline Philydor rufus & 0 & 1 & 0 & 1 & 0000000000 & 000000000 & 0000 & 0000001111 \\
\hline Phyllomyias burmeisteri & 0 & o & 0 & 1 & 0000000000 & 000000000 & 0000 & 0000001111 \\
\hline Phylloscartes superciliaris & 0 & 0 & o & I & 0000000000 & 000000000 & 0000 & $00000111 \times 1$ \\
\hline Piaya cayana & 0 & 1 & 0 & I & 1 I $11 \times \times \times \times \times \times$ & $x \times 11 \times x I x \times$ & $111 x$ & $\begin{array}{llllllllll}1 & 1 & 1 & 1 & 1 & 1 & 1 & 1 & 1 & 1\end{array}$ \\
\hline Picoides villosus & $i$ & o & 1 & 0 & $X I 1011111 X$ & $x \times x+11111 x$ & $111 x$ & $11 \times 11 \times 1111$ \\
\hline Piculus auricularis & 0 & 1 & 0 & o & 0000000000 & $11 \times 111000$ & 0000 & 0000000000 \\
\hline Piculus rubiginosus & o & 1 & o & 0 & $11 \times 1 \times 1 \times \times 1 \times$ & $0000001 \times x$ & 0000 & $\begin{array}{llllllllll}1 & 1 & 1 & 1 & 1 & 1 & 1 & 1 & 1\end{array}$ \\
\hline Pionopsitta haematotis & 0 & 1 & 0 & 1 & 0001010100 & 000000000 & 0000 & $0 \times x \times 111111111$ \\
\hline Pionts senilis & 0 & 1 & 0 & o & $11 \times \times 0 \times 0 \times \times \times$ & $0000001 \times x$ & 0000 & 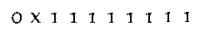 \\
\hline Pipilo erythrophthalmus & 1 & I & 1 & o & 11101111111 & $1110110 \times 1$ & 0111 & 1100000000 \\
\hline Pipilo ocai & 1 & 0 & o & o & 0010111100 & $01 \times 111000$ & 1000 & 0000000000 \\
\hline Pipra pipra & o & I & 0 & 1 & 0000000000 & 000000000 & 0000 & 0000000111 \\
\hline Piranga bidentata & $\circ$ & o & 0 & 0 & $1 \times 1001001 \times$ & 01111111111 & I I I $x$ & $1111 \times \times \times 111$ \\
\hline Piranga erythrocephaia & 1 & 0 & 1 & 0 & $00000 \times 1100$ & 111111000 & $x 1 \times x$ & 0000000000 \\
\hline Piranga flava & 1 & 1 & 1 & o & $X X I X I I 11 X X$ & $1 X 1111111 X$ & $111 x$ & $X \begin{array}{lllllllll} & 1 & 1 & 1 & 1 & 1 & 1 & 1 & 1\end{array}$ \\
\hline Piranga leticoptera & 0 & 1 & o & 1 & $1111010 \times \times x$ & $00000011 \times$ & 0000 & 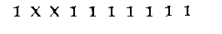 \\
\hline Platyrinchus cancrominus & 0 & 1 & 0 & o & $00 \times 1010 \times \times x$ & 000000000 & 0000 & $1 \times \times 1110000$ \\
\hline Platyrinchus mystaceus & o & 1 & o & 1 & 0000000000 & 000000000 & 0000 & 0000011111 \\
\hline Premnoplex brumescens & o & 0 & o & 1 & 0000000000 & 000000000 & 0000 & 0000011111 \\
\hline Procnias tricarunculata & o & 0 & 0 & o & 0000000000 & 000000000 & 0000 & 0001111111 \\
\hline Pselliophorus tibialis & 0 & 0 & 0 & o & 0000000000 & 000000000 & 0000 & 0000001111 \\
\hline
\end{tabular}


Appendix 1 (cont.)

\begin{tabular}{|c|c|c|c|c|c|c|c|c|}
\hline & \multirow{2}{*}{\multicolumn{2}{|c|}{ HAB }} & \multirow{2}{*}{\multicolumn{2}{|c|}{ GEO }} & \multicolumn{3}{|c|}{ Mexico } & \multirow{3}{*}{ Central America } \\
\hline & & & & & East slope & West slope & TV Belt & \\
\hline & \multicolumn{2}{|c|}{ A B } & \multicolumn{2}{|c|}{ NS } & & & & \\
\hline Pselliophorus luteotiridis & 0 & 0 & 0 & 0 & 0000000000 & 000000000 & 0000 & 0000000001 \\
\hline Pseudocolaptes lazencif & o & 0 & 0 & 1 & 0000000000 & 000000000 & 0000 & 0000001111 \\
\hline Ptilogonys caudatus & 0 & 0 & 0 & o & 0000000000 & 000000000 & 0000 & 0000000111 \\
\hline Ptilogonys cinereus & 1 & 0 & 1 & o & $11100111111 \times$ & $1 \times 111101 \times$ & $111 x$ & $11 \times 0000000$ \\
\hline Pyrrhura hotfmanni & 0 & 0 & 0 & 0 & 0000000000 & 000000000 & 0000 & 0000000011 \\
\hline Ramphocelus sanguinolentis & 0 & 1 & o & 0 & $0011010 \times x \times$ & 000000000 & 0000 & $x \times x \times 11111111$ \\
\hline Regulus satrapn & 1 & o & 1 & 0 & $00000010 \times x$ & $00 \times 1000 \times 1$ & $1 \times \times x$ & $\times 1 \times 0000000$ \\
\hline Rhynchocyclus brevirostris & 0 & 1 & 0 & 1 & $00110100 \times x$ & $0001111 \times x$ & 0000 & $\begin{array}{llllllllll}1 & 1 & 1 & 1 & 1 & 1 & 1 & 1 & 1 & 1\end{array}$ \\
\hline Rhynchopsitta pachyrhyncha & o & 0 & 1 & 0 & 0000000000 & $x \times 0000000$ & 1000 & 0000000000 \\
\hline Rhynchopsitta terrisi & 1 & o & 1 & 0 & 1000000000 & 000000000 & 0000 & 0000000000 \\
\hline Ridgwayia pinicola & 1 & 0 & 1 & o & $0 \times 10 \times 1 \times 00$ & $x 111 \times 1000$ & $x \times x \times$ & 0000000000 \\
\hline Sayomis nigricans & 1 & 1 & 1 & 1 & $111 \times \times \times \times \times \times 1$ & $1 \times \times \times \times \times \times \times x$ & $x \times x \times$ & 111111111111 \\
\hline Sclerurus albigularis & 0 & 0 & 0 & 1 & 0000000000 & 000000000 & 0000 & 0000001111 \\
\hline Sclerurus mexicanus & 0 & 0 & o & 1 & $001 \times 0100 \times x$ & 000000110 & 0000 & $\begin{array}{lllllllll}1 & 1 & 1 & 1 & \times & 1 & 1 & 1 & 1\end{array}$ \\
\hline Scytalopus argentifrons & 0 & $\circ$ & 0 & o & 0000000000 & 000000000 & 0000 & 0000011111 \\
\hline Selasphorus ardens & 0 & o & o & 0 & 0000000000 & 000000000 & 0000 & 0000000001 \\
\hline Selasphonis flammula & 0 & o & 0 & o & 0000000000 & 000000000 & 0000 & 0000000111 \\
\hline Selasphorus platycercus & 1 & 0 & 1 & o & $x \times x \circ x \times 1 \times x$ & $1 \times 11 \times x \times x \times$ & $x \times 1 x$ & $1 \times 00000000$ \\
\hline Selasphorus scintilla & o & o & 0 & o & 0000000000 & 000000000 & 0000 & 0000001111 \\
\hline Semnornis frontzil & 0 & o & 0 & o & 0000000000 & 000000000 & 0000 & 0000001111 \\
\hline Serpophaga cinerea & 0 & 0 & 0 & 1 & 0000000000 & 000000000 & 0000 & 0000001111 \\
\hline Sitta carolinensis & 1 & 0 & 1 & o & $x \times x 0101000$ & $x \times 11111000$ & $x \times x \times$ & 0000000000 \\
\hline Sitta pygmaea & 1 & 0 & 1 & 0 & $x \times 10000000$ & $x \times 1000000$ & $x \times x \times$ & 0000000000 \\
\hline Sittasomus griseicapillus & o & 1 & 0 & 1 & $11 \times 101001 \times$ & $0111011 \times x$ & 0000 & $1 \times 11 X 111111$ \\
\hline Spizaetus ornatus & 0 & 1 & o & 1 & $1 \times \times 1 \times 1 \times \times \times \times$ & 000100000 & 0000 & $x \times x \times 1 \times x \quad 1 \quad 1 \quad 1111$ \\
\hline Streptoprocne semicollaris & o & 1 & o & 0 & 0000000000 & $x \times 1100000$ & $x \times 00$ & 0000000000 \\
\hline Streptoprocne zonaris & 0 & 1 & 0 & 1 & $\begin{array}{lllllllll}1 & 1 & 1 & 0 & 1 & 1 & 1 & 1 & x\end{array}$ & $000 \times 111 \times 1$ & $x 010$ & $\begin{array}{lllllllllll}1 & 1 & 1 & 1 & 1 & 1 & X & 1 & 1 & 1\end{array}$ \\
\hline Strix fulvescents & $\circ$ & 0 & 0 & 0 & $000000001 \times$ & 000000011 & 0000 & 1111000000 \\
\hline Strix raria & 1 & o & 1 & 0 & $0 \times 00001000$ & $0 \times 100000$ & 0000 & 0000000000 \\
\hline Syndactyla subalaris & o & 0 & 0 & 1 & 0000000000 & 000000000 & 0000 & 0000011111 \\
\hline Tangara cabanisi & o & 0 & 0 & 0 & 0000000000 & 000000011 & 0000 & 1000000000 \\
\hline Tangara dowii & 0 & 0 & 0 & o & 0000000000 & 000000000 & 0000 & 0000001111 \\
\hline Tangara gyrola & o & 1 & 0 & 1 & 0000000000 & 000000000 & 0000 & 0000001111 \\
\hline Tangara icterocephala & 0 & 0 & 0 & 1 & 0000000000 & 000000000 & 0000 & 0000011111 \\
\hline Terenura callinota & o & o & 0 & 1 & 0000000000 & 000000000 & 0000 & 0000001111 \\
\hline Thalurania ridgwayi & o & 1 & 0 & 0 & 0000000000 & 010000000 & 0000 & 0000000000 \\
\hline Thamnophilus doliatus & o & 1 & 0 & 1 & $1111010 \times \times 1$ & $00000011 \mathrm{x}$ & 0000 & $1 \times \times 1 \times 11111$ \\
\hline Thraupis abbas & o & 1 & o & o & $1111010 x 1 x$ & $0000001 \times 1$ & 0000 & $1 \times 11100000$ \\
\hline Thripadectes rufobrunneus & o & o & o & o & 0000000000 & 000000000 & 0000 & 0000011111 \\
\hline Thryothorus maculipectus & o & 1 & 0 & o & $111101011 \mathrm{X}$ & $0000000 \times x$ & 0000 & $1 \times 11100000$ \\
\hline Thryothorus modestus & 0 & 1 & 0 & o & 0000000000 & $000000 \times x \times$ & 0000 & $1 \times \times 1 \times 11111$ \\
\hline Thryothorus rufalbus & 0 & 1 & o & o & 0000000000 & 000000011 & 0000 & $x \times x \times \times 00000$ \\
\hline Tityra semifasciata & 0 & 1 & 0 & 1 & $1111010 \times x \times$ & $x \times x+x 11 x x$ & 0000 & $\begin{array}{llllllllll}1 & 1 & 1 & 1 & 1 & 1 & 1 & 1 & 1 & 1\end{array}$ \\
\hline Tolmomyias sulphurescens & o & $\mathfrak{I}$ & o & 1 & $0011010 \times x \times$ & $0000001 \times x$ & 0000 & $1 \times 11 \times 11111$ \\
\hline Touit costaricensis & o & 1 & 0 & o & 0000000000 & 000000000 & 0000 & 0000000111 \\
\hline Toxostoma ocellatum & 0 & 1 & 0 & o & 0010001000 & 000010000 & $0 \times 1 \times$ & 0000000000 \\
\hline Troglodytes brumeicollis & 0 & 0 & 1 & 0 & $X 111111100$ & $x \times 1111000$ & $111 x$ & 0000000000 \\
\hline Troglodytes ochraceus & 0 & 0 & 0 & 0 & 0000000000 & 000000000 & 0000 & 0000001111 \\
\hline Troglodytes rufociliatus & 0 & 0 & o & o & $000000001 \times$ & 000000011 & 0000 & 1111100000 \\
\hline Trogon aurantizentris & 0 & o & o & o & 0000000000 & 000000000 & 0000 & 0000011111 \\
\hline Trogon collaris & 0 & 1 & 0 & 1 & $01110100 \times x$ & $00011111 X$ & 0000 & $1 \times 11100111$ \\
\hline Trogon elegans & 1 & 0 & 1 & 0 & $11 \times 00001 \times x$ & $111 \times 0101 \times$ & $x \times 00$ & $1 \times 11 \times 10000$ \\
\hline Trogon mexicanus & 1 & 0 & 1 & 0 & $111011111 x$ & $11111101 x$ & 1110 & 1111000000 \\
\hline Turdus assimilis & o & 1 & 0 & 1 & IIIIOIIIXI & $\begin{array}{lllllllll}1 & 1 & 1 & 1 & 1 & 1 & 1 & 1 & 1\end{array}$ & 1110 & $\begin{array}{lllllllllll} & X & X & 1 & 1 & 1 & 1 & 1 & 1 & 1\end{array}$ \\
\hline Turdus grayi & 0 & 1 & 0 & 1 & $111101001 \mathrm{x}$ & $00000011 \times$ & $0 \times 00$ & $1 X 1111111 X$ \\
\hline Turdus infuscatus & 0 & 0 & 0 & 0 & $11111011111 X$ & 000111111 & 0000 & 1111000000 \\
\hline Turdus migratorius & 1 & 0 & 1 & $\circ$ & $\times 110111100$ & $x X I 11110000$ & $\times 1 \times 1$ & 0000000000 \\
\hline Turdus nigrescens & 0 & 0 & o & 0 & 0000000000 & 000000000 & 0000 & 0000000111 \\
\hline Turitus plebejus & 0 & 0 & $\circ$ & 0 & 0000000000 & 000000111 & 0000 & $\begin{array}{lllllllllll}1 & 1 & 1 & 1 & 1 & 1 & 1 & 1 & 1 & 1\end{array}$ \\
\hline
\end{tabular}


Appendix 1 (cont.)

\begin{tabular}{|c|c|c|c|c|c|c|c|c|}
\hline & \multirow{2}{*}{\multicolumn{2}{|c|}{$\mathrm{HAB}$}} & \multirow{2}{*}{\multicolumn{2}{|c|}{ GEO }} & \multicolumn{3}{|c|}{ Mexico } & \multirow[b]{2}{*}{ Central America } \\
\hline & & & & & East slope & West slope & TV Belt & \\
\hline & A & & $\mathrm{N}$ & $S$ & & & & \\
\hline Turdus rufitorques & 0 & 0 & 0 & 0 & 0000000011 & $0000000 \times 1$ & 0000 & III1000000 \\
\hline Tuto alha & 1 & 1 & 1 & 1 & $x \times 11 \times \times \times \times x \times$ & $x \times x I X x I X x$ & $x \times \times 1$ & $1 \times 1 \times \times 1$ I 1111 \\
\hline Venilom fumigatus & 0 & 1 & 0 & 1 & $11 \times 1 \times 1 \times \times \times \times$ & $0 \times x 1 \times \times \times 1 \times$ & $0 \times 00$ & $x \times x \times 11111111111$ \\
\hline Vireo brezipennis & 0 & 1 & $\mathrm{o}$ & o & $0010000 \times 00$ & 010011000 & 0010 & 0000000000 \\
\hline lireo camioli & 0 & 0 & 0 & o & 0000000000 & 000000000 & 0000 & 0000000111 \\
\hline Fireo huttoni & 1 & o & 1 & 0 & 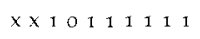 & 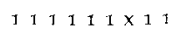 & $1 \times 1 \times$ & 1110000000 \\
\hline Tireo lewcophrys & 0 & 0 & 0 & 1 & $11100 \times 0 \times 1 \times$ & $0000001 \times x$ & 0000 & $x \times x \quad 1 \times 0011111$ \\
\hline Vireo solitarius & 1 & 0 & 1 & 0 & $x \times 10101 \times x \times$ & $O X 11111 X x$ & $111 x$ & 1111000000 \\
\hline Iireolanius melitophrys & 0 & 1 & 0 & 0 & $0110001 \times \times \times$ & OIIII $10 \times x$ & 1110 & 1000000000 \\
\hline \multicolumn{9}{|l|}{ Xiphocolaptes } \\
\hline promeropirlynchus & 0 & 1 & 0 & 1 & $01 \times \times 0111111$ & 000101000 & 0000 & 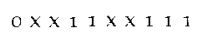 \\
\hline Xiphorhunchus erythropygius & 0 & 0 & 0 & 1 & $01 \times 0010 \times 1 \times$ & $00010011 x$ & 0000 & $\begin{array}{llllllllllll} & X & 1 & 1 & 1 & 1 & 1 & 1 & 1 & 1\end{array}$ \\
\hline Xiphorlunchus flavignster & 0 & I & 0 & 1 & $1111 \times x \times x 1 \times$ & $x 1 \times x \times x 1 \times x$ & 0000 & $1 \times 111 \times 0000$ \\
\hline Zeledonin coronata & 0 & 0 & o & 0 & 0000000000 & 000000000 & 0000 & 0000011111 \\
\hline Zimmerius itissimns & 0 & 1 & 0 & 1 & $00000000 \times x$ & $00000001 \mathrm{x}$ & 0000 & $1111 X 1111 \times$ \\
\hline
\end{tabular}

\section{Appendix 2. Descriptions of the 33 humid montane forest patches included in this study.}

HPO, humid pine-oak forest; CF, cloudforest. General references are listed in the Methods section; here listed as references are major sources that provided numerous records for particular islands.

\begin{tabular}{|c|c|c|c|}
\hline Abbreviation & Name & Habitat & References \\
\hline \multicolumn{4}{|l|}{ Eastem Mexico } \\
\hline 1. TAMPS & Tamaulipas and Nuevo León & $\mathrm{HPO}, \mathrm{CF}$ & Harrell (1951) \\
\hline 2. HIDAL & N Veracruz, Hidalgo, SLP & $\mathrm{HPO}, \mathrm{CF}$ & $\begin{array}{l}\text { Sutton and Burleigh (1940), } \\
\text { Lowery and Newman (1949) }\end{array}$ \\
\hline 3. CVERA & Central Veracruz & $\mathrm{HPO}, \mathrm{CF}$ & $\begin{array}{l}\text { Chapman (1898), } \\
\text { Navarro-Sigüenza et al. } \\
\text { (1991) }\end{array}$ \\
\hline 4. TUXTL & Los Tuxtlas, Veracruz & CF & $\begin{array}{l}\text { Wetmore (1943), Andrle } \\
(1967)\end{array}$ \\
\hline 5. CUATR & Sierra de Cuatro Venados, Oaxaca & $\mathrm{HPO}$ & Binford (1989), Rowley (1984) \\
\hline 6. JUARE & Sierra de Juárez, Oaxaca & $\mathrm{HPO}, \mathrm{CF}$ & $\begin{array}{l}\text { Binford (1989), } \\
\text { Torres-Chávez (1992) }\end{array}$ \\
\hline 7. FELIP & Cerro San Felipe, Oaxaca & $\mathrm{HPO}$ & Binford (1989) \\
\hline 8. ZEMPO & Cerro de Zempoaltépetl, Oaxaca & $\mathrm{HPO}, \mathrm{CF}$ & Binford $(1989)$ \\
\hline 9. SCRIS & San Cristóbal de lās Casas, Chiapas & $\mathrm{HPO}, \mathrm{CF}$ & Alvarez del Toro (1980) \\
\hline IO. MONTE & Lagunas de Montebello, Chiapas & $\mathrm{HPO}, \mathrm{CF}$ & Alvarez del Toro (1980) \\
\hline \multicolumn{4}{|l|}{ Western Mexico } \\
\hline 11. SINDU & Sinaloa and Durango & $\mathrm{HPO}$ & - \\
\hline 12. NAYJA & Nayarit and Jalisco & $\mathrm{HPO}$ & $\begin{array}{l}\text { Escalante-Pliego (1988), } \\
\text { Schaldach (1963) }\end{array}$ \\
\hline 13. $\mathrm{MICHO}$ & Coastal Michoacán & $\mathrm{HPO}$ & - \\
\hline 14. GUERR & Sierra de Atoyac, Guerrero & $\mathrm{HPO}, \mathrm{CF}$ & $\begin{array}{l}\text { Navarro-Sigüenza (1986, } \\
\text { 1992) }\end{array}$ \\
\hline 15. YLCUN & Sierra de Yucuñacua, Oaxaca & $\mathrm{HPO}$ & Binford (1989) \\
\hline
\end{tabular}


Appendix 2 - (cont.)

\begin{tabular}{|c|c|c|c|}
\hline Abbreviation & Name & Habitat & References \\
\hline 16. MIAHU & Sierra de Miahuatlán, Oaxaca & $\mathrm{HPO}$ & Binford (1989), Rowley (1966) \\
\hline 17. CHIMA & Los Chimalapas, Oaxaca & $\mathrm{HPO}, \mathrm{CF}$ & Binford (1989) \\
\hline 18. SOCON & Sierra de Soconusco, Chiapas & $\mathrm{HPO}, \mathrm{CF}$ & $\begin{array}{l}\text { Parker et al. (1976), Alvarez } \\
\text { del Toro (1980) }\end{array}$ \\
\hline 19. TACAN & Volcán de Tacan & $\mathrm{HPO}, \mathrm{CF}$ & Alvarez del Toro (1980) \\
\hline \multicolumn{4}{|c|}{ Transvolcanic Belt, Mexico } \\
\hline 20. TANCI & Cerro de Tancítaro, Michoacán & $\mathrm{HPO}, \mathrm{CF}$ & Blake and Hanson (1942) \\
\hline 21. TEMAS & Temascaltepec, México & $\mathrm{HPO}$ & Ornelas et al. (1988) \\
\hline 22. $\mathrm{TAxCO}$ & Sierra de Taxco, Guerrero & $\mathrm{HPO}$ & $\begin{array}{l}\text { Morales-Pérez and } \\
\text { Navarro-Sigüenza (1992) }\end{array}$ \\
\hline 23. MALIN & Volcán La Malinche & $\mathrm{HPO}$ & - \\
\hline \multicolumn{4}{|c|}{ Central America } \\
\hline 24. GUAPA & Pacific slope, Guatemala & $\mathrm{HPO}, \mathrm{CF}$ & $\begin{array}{l}\text { Griscom (1932), Land and } \\
\text { Wolf (1961) }\end{array}$ \\
\hline 25. GUACU & $\begin{array}{l}\text { Sierra de los Cuchumatanes, } \\
\text { Guatemala }\end{array}$ & $\mathrm{HPO}, \mathrm{CF}$ & $\begin{array}{l}\text { Griscom (1932), Land and } \\
\text { Wolf (1961) }\end{array}$ \\
\hline 26. GUAMI & Sierra de las Minas, Guatemala & $\mathrm{HPO}, \mathrm{CF}$ & $\begin{array}{l}\text { Griscom (1932), Land and } \\
\text { Wolf (1961) }\end{array}$ \\
\hline 27. HONDU & Honduras and El Salvador & $\mathrm{HPO}, \mathrm{CF}$ & $\begin{array}{l}\text { Monroe (1968), Thurber et al. } \\
\text { (1987) }\end{array}$ \\
\hline 28. NICAR & Nicaragua & $\mathrm{HPO}, \mathrm{CF}$ & - \\
\hline 29. CRGUA & Cordillera de Guanacaste, Costa Rica & $\mathrm{HPO}, \mathrm{CF}$ & $\begin{array}{l}\text { Slud (1964), Stiles and } \\
\text { Skutch (1989) }\end{array}$ \\
\hline 30. CRTIL & Cordillera de Tilarán, Costa Rica & $\mathrm{HPO}, \mathrm{CF}$ & $\begin{array}{l}\text { Slud (1964), Stiles and } \\
\text { Skutch (1989) }\end{array}$ \\
\hline 31. CRCEN & Cordillera Central, Costa Rica & $\mathrm{HPO}, \mathrm{CF}$ & $\begin{array}{l}\text { Slud (1964), Stiles and } \\
\text { Skutch (1989) }\end{array}$ \\
\hline 32. CRTAL & Cordillera de Talamanca & $\mathrm{HPO}, \mathrm{CF}$ & $\begin{array}{l}\text { Slud (1964), Stiles and } \\
\text { Skutch (1989) }\end{array}$ \\
\hline 33. WPANA & Western Panama & $\mathrm{HPO}, \mathrm{CF}$ & Wetmore $(1965-1984)$ \\
\hline
\end{tabular}

\section{References}

Alvarez del Toro, M. (1980) Las aves de Chiapas. Tuxtla Gutiérrez, Chiapas: Gobierno del Estado de Chiapas.

Andrle, R. F. (1967) Birds of the Sierra de Tuxtla in Veracruz, Mexico. Wilson Bull. 79: $163-187$.

AOU (1983) Check-list of North American birds. Washington, D.C.: American Ornithologists' Union.

Banks, R. C. (1990) Taxonomic status of the Coquette hummingbird of Guerrero, Mexico. Auk 107: 191-192.

Baptista, L. F. (1978) A revision of the Mexican Piculus (Picidae) complex. Wilson Bull. 90: 159-181.

Binford, L. C. (1989) A distributional survey of the birds of the Mexican state of Oaxaca. Orn. Monogr. 43: 1-405.

Blake, E. R. and Hanson, H. C. (1942) Notes on a collection of birds from Michoacan, Mexico. Field Mus. Nat. Hist., Zool. Ser. 22: 513-551.

Chapman, F. M. (1898) Notes on birds observed at Jalapa and Las Vigas, Vera Cruz, Mexico. Bull. Amer. Mus. Nat. Hist. 10: 15-43. 
Collar, N. J., Gonzaga, L. P., Krabbe, N., Madroño Nieto, A., Naranjo, L. G., Parker, T. A. and Wege, D. C. (1992) Threatened birds of the Americas: the ICBP/IUCN Red Data Book. Cambridge, U.K.: International Council for Bird Preservation.

Cracraft, J. (1983) Species concepts and speciation analysis. Curr. Onn. 1: 159-187.

Escalante-Pliego, P. (1988) Las aves de Nayarit. Mexico: Universidad Autónoma de Nayarit. Escalante-Pliego, P. and Peterson, A. T. (1992) Geographic variation and species limits in Middle American woodnymphs (Thalurania). Wilson Bull, 104: 205-219.

Escalante-Pliego, P., Navarro-Sigüenza, A. G. and Peterson, A. T. (1993) A geographic, ecological, and historical analysis of land bird diversity in Mexico. Pp.281-307 in T. P. Ramamoorthy, R. Bye, A. Lot and J. Fa, eds. Biological diversity of Mexico: origins and distribution. New York: Oxford University Press.

Friedmann, H., Griscom, L. and Moore, R. T. (1950) Distributional check-list of the birds of Mexico, Part 1. Pacific Const Avifauna 29: 1-202.

Graham, A. (1993) Historical factors and biological diversity in Mexico. Pp.109-127 in T. P. Ramamoorthy, R. Bye, A. Lot and J. Fa, eds. Biological diversity of Mexico: origins and distribution. New York: Oxford University Press.

Griscom, L. (1932) The distribution of bird-life in Guatemala. Bull. Amer. Mus. Nat. Hist. 9: 1-439.

Harrell, B. E. (1951) The birds of Rancho del Cielo, an ecological investigation in the oaksweet gum forest of Tamaulipas, Mexico. Thesis, University of Minnesota.

ICBP (1992) Putting biodiversity on the map: priority areas for global conservation. Cambridge, U.K.: International Council for Bird Preservation.

Land, H. C. and Wolf, L. L. (1961) Additions to the Guatemalan bird list. Auk 78: 94-95.

Long, A. J. (1995) The importance of tropical montane cloud forests for endemic and threatened birds. Pp.79-105 in J. O. Juvik and F. N. Scatena, eds. Tropical montane cloud forests. New York: Springer-Verlag.

Lowery, G. H., Jr. and Newman, R. J. (1949) New birds from the state of San Luis Potosi and the Tuxtla Mountains of Veracruz, Mexico. Louisiana State Univ. Mus., Occas. Pap. 22: $1-10$.

Martin, P. S. and Harrell, B. E. (1959) The Pleistocene history of temperate biotas in Mexico and eastern United States. Ecology 38: $468-480$.

McKitrick, M. C. and Zink, R. M. (1988) Species concepts in ornithology. Condor 90: 1-14.

Miller, A. H., Friedmann, H., Griscom, L. and Moore, R. T. (1957) Distributional checklist of the birds of Mexico, Part 2. Pacific Coast Avifauna 33: 1-436.

Monroe, B. L., Jr. (1968) A distributional survey of the birds of Honduras. Orn. Monogr. 7: $1-458$.

Morales-Pérez, J. E. and Navarro-Sigüenza, A. G. (1992) Análisis de la distribución de las aves en la Sierra Norte del Estado de Guerrero, México. An. Inst. Biología, U.N.A.M. 62: $497-510$.

Navarro-Sigüienza, A. G. (1986) Distribución altitudinal de las aves en la Sierra de Atoyac, Guerrero. Tesis profesional, Facultad de Ciencias, U.N.A.M.

Navarro-Sigüenza, A. G. (1992) Altitudinal distribution of birds in the Sierra Madre del Sur, Guerrero, Mexico. Condor 94: 29-39.

Navarro-Sigüenza, A. G., Morales-Pérez, J. E. and Hernández-Baños, B. E. (1991) Aves de Teocelo. Teocelo 7 pp.

Navarro-Sigüenza, A. G., Peterson, A. T., Escalante-Pliego, P. and Benitez-Díaz, H. (1992) Cypseloides storeri, a new species of swift from Mexico. Wilson Bull. 104: 55-64.

Ornelas, J. F., Navarijo, L. and Chávez, N. (1988) Análisis avifaunístico de la localidad de Temascaltepec, Estado de México, México. An. Inst. Biología, U.N.A.M. 58: 373388.

Parker, T. A., III, Hilty, S. and Robbins, M. B. (1976) Birds of El Triunfo cloud forest, Mexico, with notes on the Horned Guan and other species. Amer. Birds 30: 779-782. 
Peterson, A. T. (1992) Phylogeny and rates of molecular evolution in the Aphelocoma jays (Corvidae). Auk 109: 133-147.

Peterson, A. T. (1993) Species status of Geotrygon carrikeri. Bull. Brit. Om. Club 113: 166168.

Peterson, A. T., Escalante-Pliego, P. and Navarro-Sigüenza, A. G. (1992) Genetic variation and differentiation in Mexican populations of Common Bush-tanagers and Chestnut-capped Brush-finches. Condor 94: 244-253.

Peterson, A. T., Flores-Villela, O. A., Leon-Paniagua, L. S., Llorente-Bousquets, J. E., Luis-Martínez, M. A., Navarro-Sigüenza, A. G., Torres-Chávez, M. G. and VargasFernández, I. (1993) Conservation priorities in northern Middle America: moving up in the world. Biodiversity Letters $1: 33-38$.

Ramamoorthy, T. P., Bye, R., Lot, A. and Fa, J. (1993) Biological diversity of Mexico: origins and distribution. New York: Oxford University Press.

Remsen, J. V. (1994) Use and misuse of bird lists in community and conservation. Auk 111: 225-227.

Rowley, J. S. (1966) Breeding records of birds in the Sierra Madre del Sur, Oaxaca, Mexico. Proc. Western Found. Vert. Zool. 1: 107-204.

Rowley, J. S. (1984) Breeding records of land birds in Oaxaca, Mexico. Proc. Western Found. Vert. Zool. 2: 73-224.

Rzedowski, J. (1986) Vegetación de México. Mexico City: Editorial Limusa.

Sarukhán, J. and Dirzo, R. (1992) Mexico confronts the challenges of biodiversity. Mexico City: Comisión Nacional para el Conocimiento y Uso de la Biodiversidad.

Schaldach, W. J., Jr. (1963) The avifauna of Colima and adjacent Jalisco, Mexico. Proc. Western Found. Vert. Zool. 1: 1-100.

Slud, P. (1964) The birds of Costa Rica: distribution and ecology. New York: American Museum of Natural History.

Soulé, M. E. (1990) The real work of systematics. Ann. Missouri Bot. Garden 77: 4-12.

Stiles, F. G. and Skutch, A. F. (1989) A guide to the birds of Costa Rica. Ithaca, New York: Cornell University Press.

Sutton, G. M. and Burleigh, T. D. (1940) Birds of Valles, San Luis Potosi, Mexico. Condor 42: 259-262.

Torres-Chávez, M. G. (1992) Distribución altitudinal de las aves en la Sierra de Juárez, Oaxaca. Tesis profesional, Facultad de Ciencias, U.N.A.M.

Thurber, W. A., Serrano, J. F., Sermeño, A., Benítez, M. (1987) Status of uncommon and previously unreported birds of El Salvador. Proc. Western Found. Vert. Zool. 3: 109293.

Vázquez-García, J. A. (1995) Cloud forest archipelagoes: preservation of fragmented montane ecosystems in tropical America. Pp.315-332 in J. O. Juvik and F. N. Scatena, eds. Tropical montane cloud forests. New York: Springer-Verlag.

Wetmore, A. (1943) The birds of southern Veracruz, Mexico. Proc. U.S. Natn. Mus. 93: 215-340.

Wetmore, A. (1965-1984) The birds of the Republic of Panama, Parts 1-4. Washington, D.C.: Smithsonian Institution.

\section{BLANCA E. HERNÁNDEZ-BAÑOS}

Museo de Zoología, Facultad de Ciencias, Universidad Nacional Autónoma de México, Apartado Postal 70-399, México, D.F. 04510, Mexico

\section{A. TOWNSEND PETERSON}

Natural History Museum. The University of Kansas, Lawrence, Kansas 66045, U.S.A. 


\section{ADOLFO G. NAVARRO-SIGÜENZA}

Museo de Zoología, Facultad de Ciencias, Universidad Nacional Autónoma de México, Apartado Postal 70-399, México, D.F. 04510, Mexico

\section{PATRICIA ESCALANTE-PLIEGO}

Departamento de Zoología, Instituto de Biología, Universidad Nacional Autónoma de México, Apartado Postal 70-153, México, D.F. 04510, Mexico 